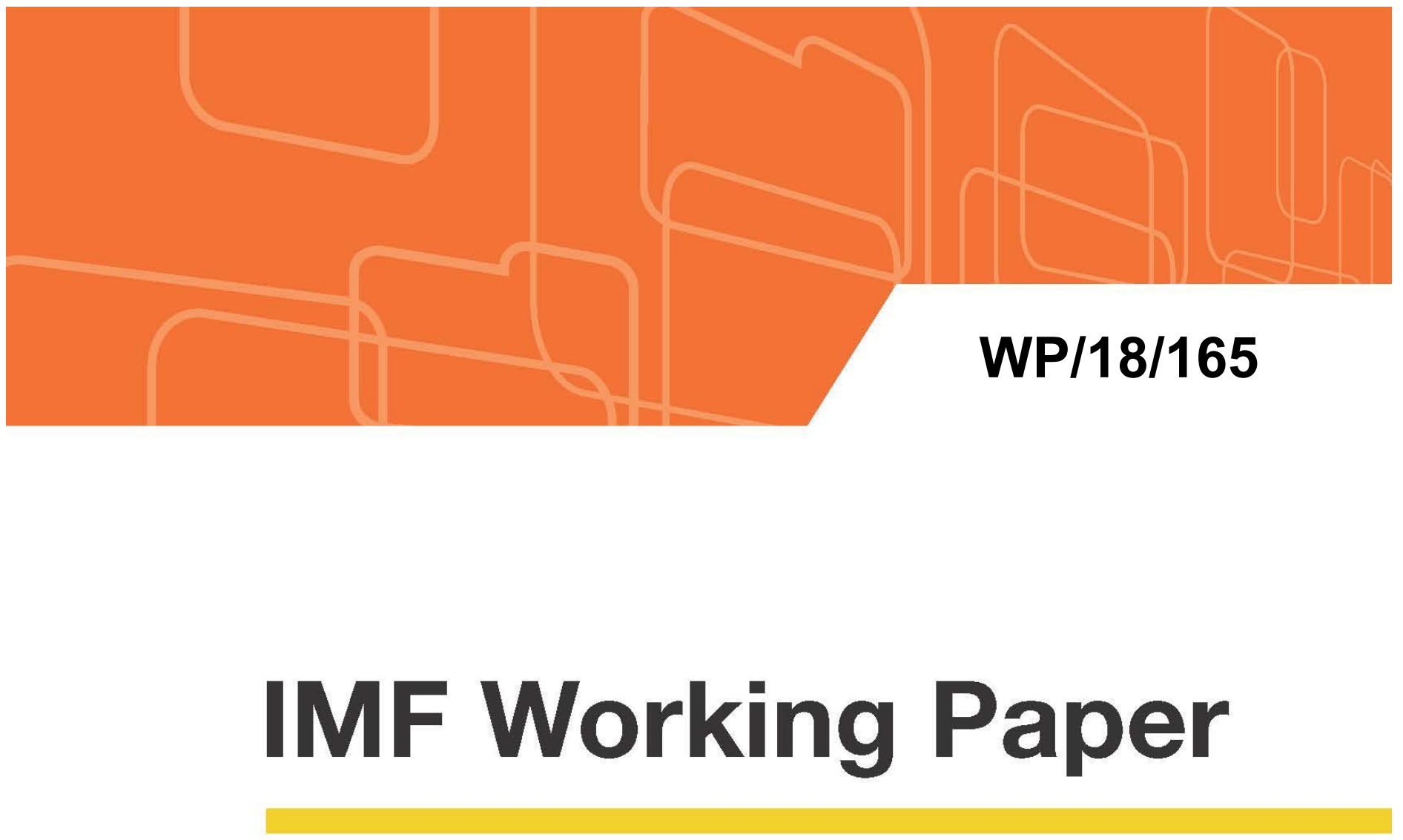

\title{
Still Attached? Are Social Safety Nets Working? Labor Force Participation in European Regions
}

IMF Working Papers describe research in progress by the author(s) and are published to elicit comments and to encourage debate. The views expressed in IMF Working Papers are those of the author(s) and do not necessarily represent the views of the IMF, its Executive Board, or IMF management. 


\title{
IMF Working Paper
}

Research Department

\section{Still Attached? Are Social Safety Nets Working? Labor Force Participation in European Regions}

\author{
Prepared by Benjamin Hilgenstock and Zsóka Kóczán ${ }^{1}$ \\ Authorized for distribution by Oya Celasun
}

July 2018

\section{IMF Working Papers describe research in progress by the author(s) and are published to elicit comments and to encourage debate. The views expressed in IMF Working Papers are those of the author(s) and do not necessarily represent the views of the IMF, its Executive Board, or IMF management.}

\begin{abstract}
The paper examines the evolution and drivers of labor force participation in European regions, focusing on the effects of trade and technology. As in the United States, rural regions within European countries saw more pronounced declines (or smaller increases) in participation than urban regions. Unlike in the United States, however, trade and technology, captured here using novel measures of initial exposures to routinization and offshoring, did not result in detachment from the workforce in European regions. Instead, regions with high initial exposures to routinization and offshoring experienced so-far larger increases in participation, likely driven by an added second worker effect.

JEL Classification Numbers: F16, F66, J21, J23, R12

Keywords: Labor force participation, exposure to routinization, exposure to offshoring, technology, automation

Author's E-Mail Addresses: bhilgenstock@iif.org; zkoczan@imf.org

\footnotetext{
${ }^{1}$ The authors would like to thank Oya Celasun, Jiri Podpiera, Alasdair Scott and Petia Topalova for very helpful comments on earlier drafts of the paper.
} 


$\begin{array}{lr}\text { Abstract } & 2 \\ \text { I. Introduction } & 4 \\ \text { II. Literature } & 7 \\ \text { III. Data } & 8 \\ \text { IV. Stylized Facts } & 9 \\ \text { V. Empirical Strategy and Results } & 12 \\ \text { VI. Conclusions } & 19 \\ \text { References } & 21\end{array}$

\section{Figures}

Figure 1. Demographic Transition in European Economies, 1960-2100___ 4

Figure 2. Changes in Life Expectancy in Advanced Economies ___ 5

Figure 3. Evolution of Labor Force Participation Rates, 1990-2016 __ 5

Figure 4. Heterogeneity of Developments in Labor Force Participation ___ 7

Figure 5. Convergence of Labor Force Participation Rates ___ 8

Figure 6. Changes in Labor Force Participation Rates, 2000-2016 __ 9

Figure 7. Population Density and Changes in Labor Force Participation Rates___ 10

Figure 8. Changes in Labor Force Participation Rates ___ 10

Figure 9. Changes in Labor Market Dynamics____ 11

Figure 12. Exposures to Routinization and Offshoring and Subsequent Changes in Exposures

Figure 14. Additional Drivers of Changes in Labor Force Participation Rates ___ 16

Figure 15. Model Fit___ 17

Figure 16. Contributions to Changes in Labor Force Participation Rates, 2000-2016___ 17

Figure 17. Contributions of Exposures to Routinization and Offshoring and Changes in Labor

Force Participation Rates

Figure 18. Exposures to Routinization and Offshoring and Change in Female Labor Force Participation

Appendix Figure 1. Changes in Labor Market Dynamics, Individual Regions

\section{Tables}

Table 1. Drivers of Labor Force Participation Rates in European Regions 


\section{INTRODUCTION}

In most European economies, dependency rates have increased considerably since the 1960 s, driven by a combination of slow population growth and increasing life expectancy. As these trends gather pace, dependency ratios are projected to reach a striking 50 percent in more than three-quarters of countries by 2050 (Figures 1 and 2). These demographic trends weigh on labor force participation rates, and challenge the sustainability of social insurance schemes going forward. ${ }^{2}$

So far, however, participation rates have increased in the majority of European countries, and exhibited convergence, especially from the bottom (Figure 3 ). ${ }^{3}$ This rise in participation rates stands in contrast with the stark decline in participation observed in the United States (see Chapter 2 of the April 2018 World Economic Outlook), despite milder demographic pressures (Figure 2). The large literature on the declining labor force participation rates in the United States highlighted the forces of trade and technology, suggesting that the disappearance of jobs due to automation and globalization may have led to the permanent detachment of some of the affected workers from the workforce (see Acemoglu and

\section{Figure 1. Demographic Transition in European Economies, 1960-2100}

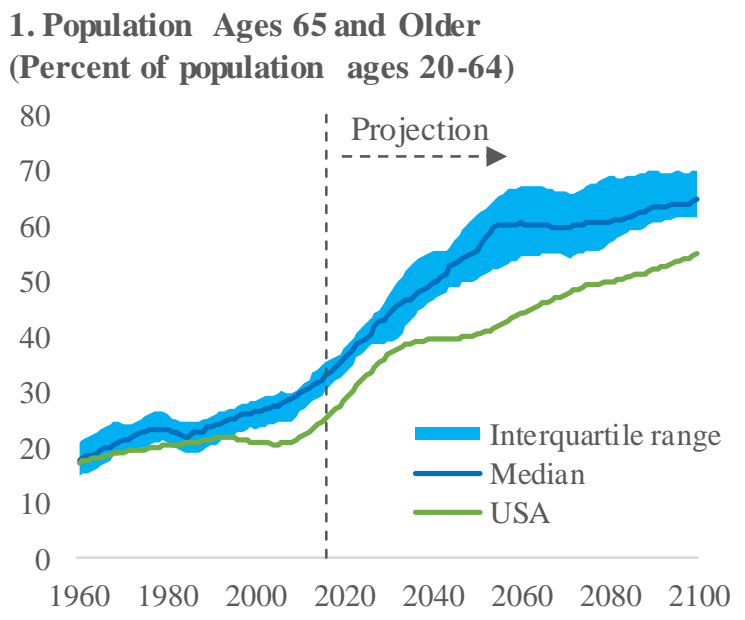

2. Population Growth

(Percent)

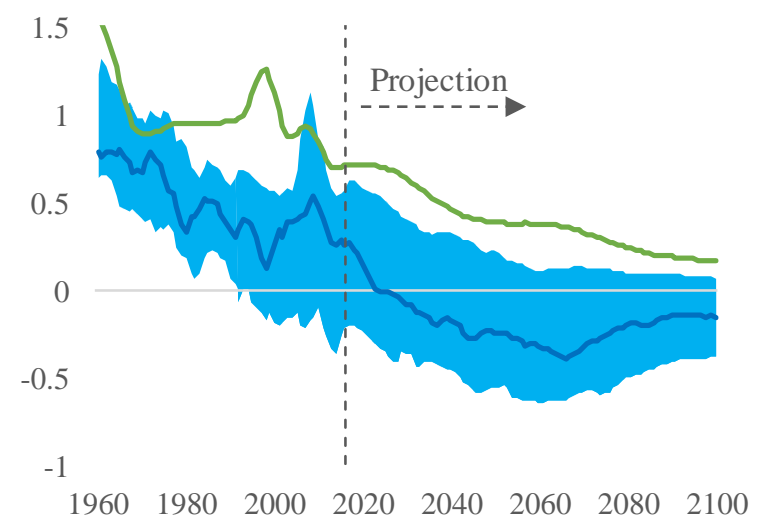

Sources: United Nations; and authors' calculations. Note: Countries included in summary statistics are AUT, BEL, BGR, CHE, CYP, CZE, DEU, DNK, ESP, EST, FIN, FRA, GBR, GRC, HRV, HUN, IRL, ISL, ITA, LTU, LUX, LVA, MLT, NLD, NOR, POL, PRT, ROU, SVK, SVN, and SWE.

\footnotetext{
${ }^{2}$ The median European economy's population grew at only one fourth of a percent in 2016 and more then half of countries will see negative growth rates by 2025 (Figure 1, panel 2). The median country's life expectancy increased by more than 12 years over the course of the past five and a half decades (Figure 2, panel 1). Healthy life expectancy also increased: by 3.6 years for men and by 2.8 years for women in the median European country between 1990 and 2015 (Figure 2, panel 2).

${ }^{3}$ Numbers are based on a balanced panel of 237 non-overlapping NUTS regions from 28 European advanced as well as emerging market and developing economies. Data is available for regions from the following countries: AUT, BEL, BGD, CYP, CZE, DEU, ESP, EST, FIN, FRA, GBR, GRC, HUN, IRL, ISL, ITA, LTU, LUX, LVA, MLT, NLD, NOR, POL, PRT, ROU, SVK, SVN, and SWE.
} 
Figure 2. Changes in Life Expectancy in Advanced Economies

1. Life Expectancy at Birth, 1960-2015

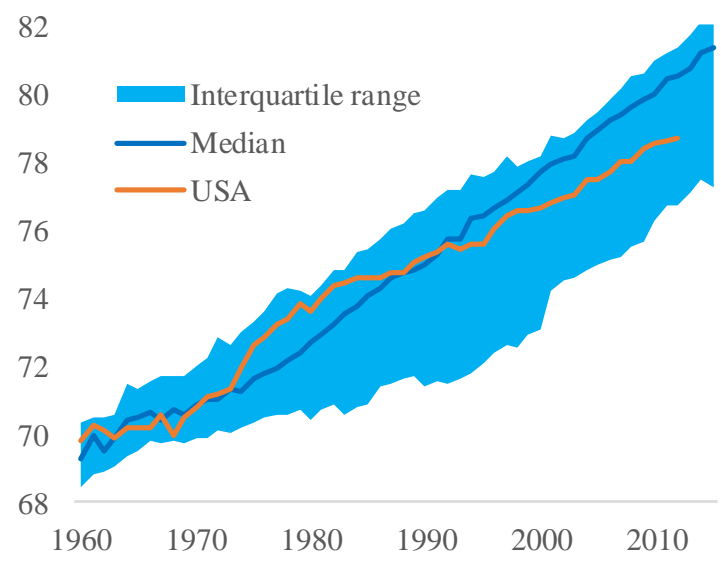

2. Healthy Life Expectancy by Sex, 1990 and 2010

$$
\begin{array}{ll}
72 & \square \text { Men } \\
70 & \square \text { Women } \\
68 & \text { oUSA }
\end{array}
$$

66

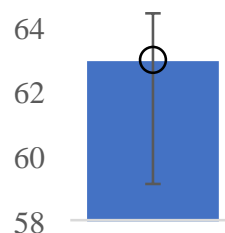

1990

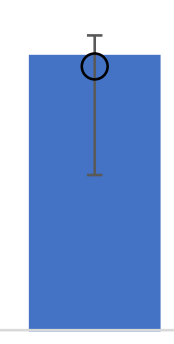

2010

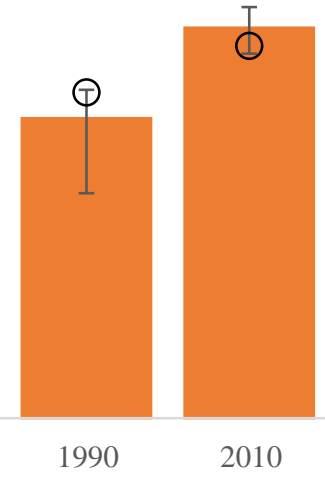

2010

Sources: United Nations; and authors' calculations Note: Countries included in summary statistics are AUT, BEL, BGR, CHE, CYP, CZE, DEU, DNK, ESP, EST, FIN, FRA, GBR, GRC, HRV, HUN, IRL, ISL, ITA, LTU, LUX, LVA, MLT, NLD, NOR, POL, PRT, ROU, SVK, SVN, and SWE.

Figure 3. Evolution of Labor Force Participation Rates, 1990-2016

(Percent)

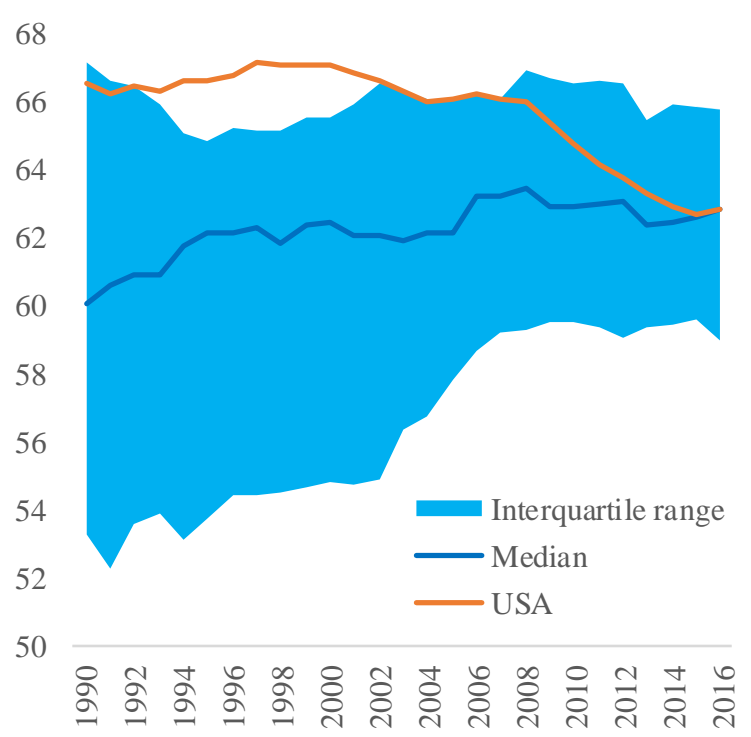

Sources: Organis ation for Economic Co-operation and Development; and authors' calculations.

Note: European countries included are AUT, BEL, CHE, CZE, DEU, DNK, ESP, EST, FIN, FRA, GBR, GRC, IRL, ISL, ITA, LUX, NLD, NOR, PRT, SVK, and SWE. Abbreviations in the footnote use International Organization for Standardization (ISO) country codes . Summary statistics are based on balanced panel starting in 1995.

Restrepo 2017, Autor, Dorn and Hanson 2016, Council of Economic Advisers 2016, Krause and Sawhille 2017). Recent work also emphasized widening geographic disparities in such trends, and their political economy implications (see Austin, Glaeser

and Summers 2018, Brooks and others 2017a, b, c). In contrast, most of the literature on labor force participation in Europe focused on the role of policies and age and cohort effects, especially on the participation of women and older workers, with until recently little emphasis on the potential role of trade and automation in shaping participation trends over the past cople of decades. Notable recent exceptions include Gregory, Salomons and Zierahn (2016) and Graetz and Michaels (2015), who have noted that the impact of technology may be different in Europe.

This paper aims to contribute to this literature by examining the evolution and drivers of labor force participation rates in Europe, looking at heterogeneity across European 
regions, and zooming in on the effects of automation and offshoring. In particular, the paper first examines to what extent the increase in participation rates observed in most European countries was uniform within each country, or whether there is evidence of significant regional effects. Second, using variation across Europe's subnational regions in demographic shifts, cyclical conditions, and education, it teases out the role of aging, educational gains, and economic growth. Finally, the paper builds novel measures of regional exposure to routinization and offshoring based on the occupational structure of the labor force to study the influence of the global forces of trade and technology. It is a companion paper to Hilgenstock and Koczan (2018), which applies a similar empirical strategy to examine participation rates in states and metropolitan areas in the United States. This paper aims to follow the methodology used there as closely as possible in order to allow for comparability of results, and focus attention on differences in findings rather than approaches. In particular, the novel local exposures to routinization and offshoring are constructed following a similar methdology.

The paper documents considerable heterogeneity across European regions in terms of changes in labor force participation rates. Similar to the United States, rural regions appear to confront more pronounced declines (or smaller increases) in participation compared to more urban regions.

The empirical results suggest that, while aging and cyclical conditions weighed on participation rates, these drags were more than offset by a striking rise in educational attainment. Strikingly, unlike in the United States, the forces of trade and technology did not result in detachment from the workforce in European regions on average, once labor markets had time to adjust. Instead, regions with high initial exposures to routinization and offshoring experienced so-far larger increases in participation. These include economically diverse urban regions (such as London, Paris, Madrid, Catalonia), some 'old industrial regions' (for instance in Northern Italy, Sweden and Switzerland, where automation may not have progressed as fast as in the US yet, or displaced workers found alternative employment instead of becoming detached from the workforce), as well as regions in Emerging Europe (parts of the Czech Republic and Hungary), which benefited from offshoring on the receiving end and saw gains in employment and participation as a result of increased integration in regional supply chains. This could be driven by an added second worker effect: higher initial exposures to routinization and offshoring are associated with larger subsequent increases in women's participation.

Routinization and offshoring may, however, weigh on participation rates and challenge the sustainability of social insurance systems in the future as the forces of automation become stronger, especially in advanced Europe, and labor costs rise in emerging Europe, making these regions less attractive as destinations for offshoring.

The rest of the paper is structured as follows. Section II provides a brief review of the literature on participation in the European countries, Section III introduces the data used, and 
Section IV presents stylized facts. Section V outlines the empirical strategy, presents regression results and illustrates the relative contributions of different factors at the regional level. Section VI concludes.

\section{Literature}

There is a large literature on the drivers of, especially women's, participation in Europe, and its link to policies. Genre and others (2010) point to the effects of institutions and policies, such as part-time incentives and maternity leave, on women's participation in Europe. Thévenon (2013) emphasizes the effects of the provision of childcare services (alongside the positive effects of education, the expansion of the service sector, and increase in part-time employment opportunities), and finds these to be stronger in the presence of other measures supporting working mothers (such as paid parental leave). Cipollone and others (2013) rely on individual-level data and find that labor market reforms can account for almost 25 percent of the actual increase in the participation of young women over the preceding two decades, more than 30 percent of that of highly educated women, though with relatively small effects on the participation of low skilled women. The role of labor market policies and institutions is confirmed in Christiansen and others (2016) who document that even controlling for women's expressed attitudes towards working, policies are a key driver of female employment in Europe using individual level data. Miani and Hoorens (2014) also highlight the role of family-friendly policies.

A separate literature has examined age and cohort effects in labor force participation (how participation varies over the life cycle and across different birth cohorts, respectively), typically for single countries (see for instance Euwals and others 2007 for the Netherlands). Balleer and others (2014) explore a cohort-model for six European economies, and find that cohort effects can account for a substantial part of the recent increase in women's

\section{Figure 4. Heterogeneity of Developments in} Labor Force Participation

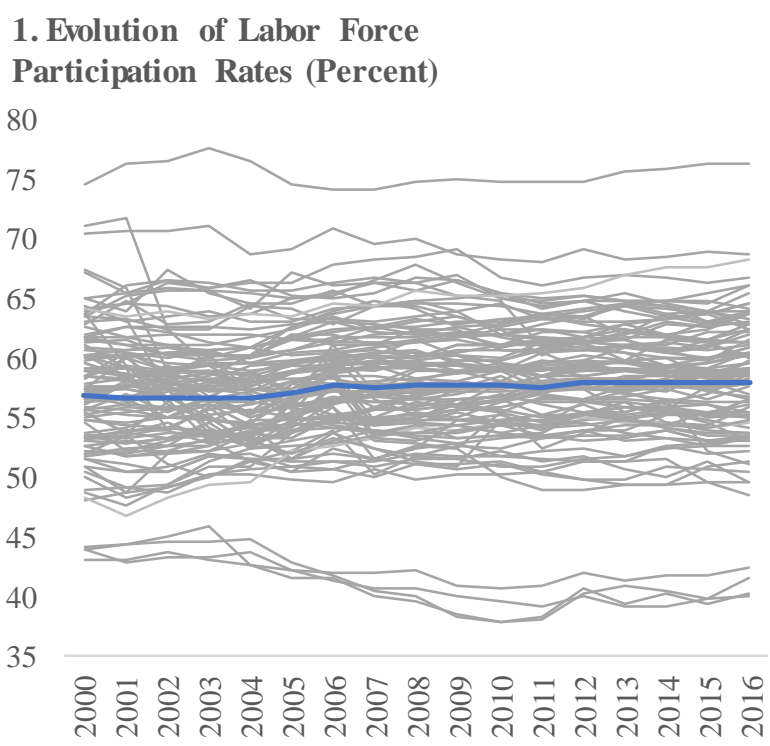

2. Evolution of Changes in Labor Force Participation Rates (Percentage points)

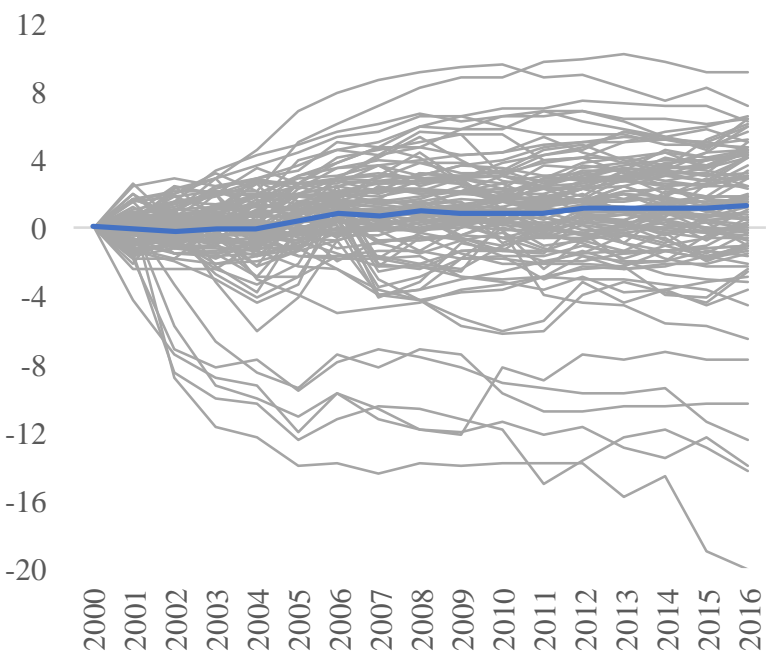

Sources: Eurostat; and authors' calculations.

Note: The 100 largest NUTS regions by 2016 total population are shown. 
participation in Spain, the Netherlands and Germany, and has a smaller though still positive contribution in the UK, Italy and France.

Recent papers focusing on the impact of technology include Gregory, Salomons, and Zierahn (2016) and Graetz and Michaels (2015). Using a crossindustry, cross-country panel, Gregory, Salomons, and Zierahn (2016) estimate that in European regions the direct employmentreducing effects of automation ('routinereplacing technical change') on middle-skill employment have been offset by compensatory effects operating through product demand and local demand spillovers. Focusing directly on robotics, Graetz and Michaels (2015) conclude that in EU countries industry-level adoption of industrial robots raised labor productivity, increased value-added, augmented worker wages, had no measurable effect on overall labor hours, and modestly shifted employment in favor of high-skilled workers.

This paper aims to contribute to this literature by (1) zooming in further on the roles of trade and technology, relying on novel measures of initial local exposures to examine how these effects differ across regions and relative to the United States, and (2) allowing for within-country differences, analyzing the evolution and drivers of participation at the level of European regions. The use of subnational data allows for a more granular assessment of drivers of participation trends since the early 2000s. The analysis uses the heterogeneity across roughly 250 regions, exploiting variation which is partially lost when aggregated to the level of the 28 countries in Europe. To the best of our knowledge this is the first paper to examine these forces at this level of disaggregation in European countries.

\section{DATA}

The paper relies on data on labor force participation rates and populations from Eurostat for Nomenclature of Territorial Units for Statistics (NUTS) regions. The paper relies on NUTS-2 regions whenever possible. In case of missing data, the paper uses NUTS-1 regions. Country-level data are used for countries for which a regional breakdown does not exist (Iceland, Latvia, Lithuania and Luxembourg). This approach generates a sample of roughly 250 regions (for a full list of regions, see Appendix Table 1). Labor market indicators are available from 2000. 
Regressions examine the effects of aging, cyclical conditions, trade and technology on participation at the regional level - these are proxied using old-age dependency ratios (defined as the population age 65 and older as a percentage of the population age 15 to 64$)$, real GDP growth rates (both from Eurostat), and measures of initial exposures to routinization and offshoring. These novel measures (from Das and Hilgenstock 2018, see also Chapter 3 of the April 2017 World Economic Outlook) act as proxies for the initial share of jobs that are at risk of being automated or offshored within a geographical unit and thus allow for a more granular analysis of local exposures to the global forces of technology and trade. The two measures are constructed as employment-weighted averages of occupational scores for routinizability and offshorability. The routinizability scores are based on scores from Autor and Dorn (2013) which measure the "routine task intensity",
Figure 6. Changes in Labor Force Participation Rates, 2000-2016

(Percentage points)

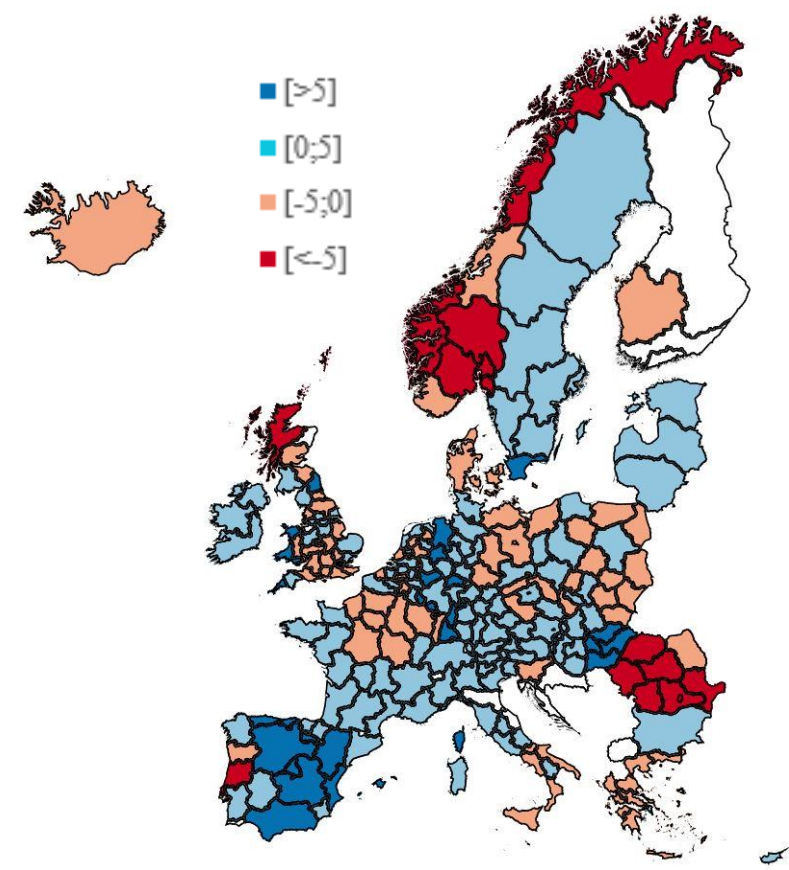

Sources: Eurostat; and authors' calculations.

Note: Regions in white denote regions for which data was not available.

or how intensive an occupation is in routine tasks, for 330 occupations based on the US Department of Labor's Dictionary of Occupational Titles. The offshorability scores rely on data by Goos, Manning, and Salomons (2014) who convert the professional coders' assessment-based measure in Blinder and Krueger (2014) into ISCO occupational categories. The employment-by-education data used in the construction of the two measures stems from the European Union Labour Force Survey (EULFS). Regressions also control for education, proxied using the share of the population within a region enrolled in tertiary education from Eurostat.

\section{STYLIZEd FACTS}

European regions exhibit considerable heterogeneity in levels as well as changes in participation rates. ${ }^{4}$ Figure 4 plots the 100 most populous regions and illustrates that participation rates range from the high 30s (in regions in Southern Italy and Romania) to the high 60s and above (in regions in Germany, the Netherlands, Sweden, and the United

\footnotetext{
${ }^{4}$ The labor force participation rate is the fraction of the adult population (ages 15 and over) either working or looking for work.
} 
Figure 7. Population Density and Changes in Labor Force Participation Rates

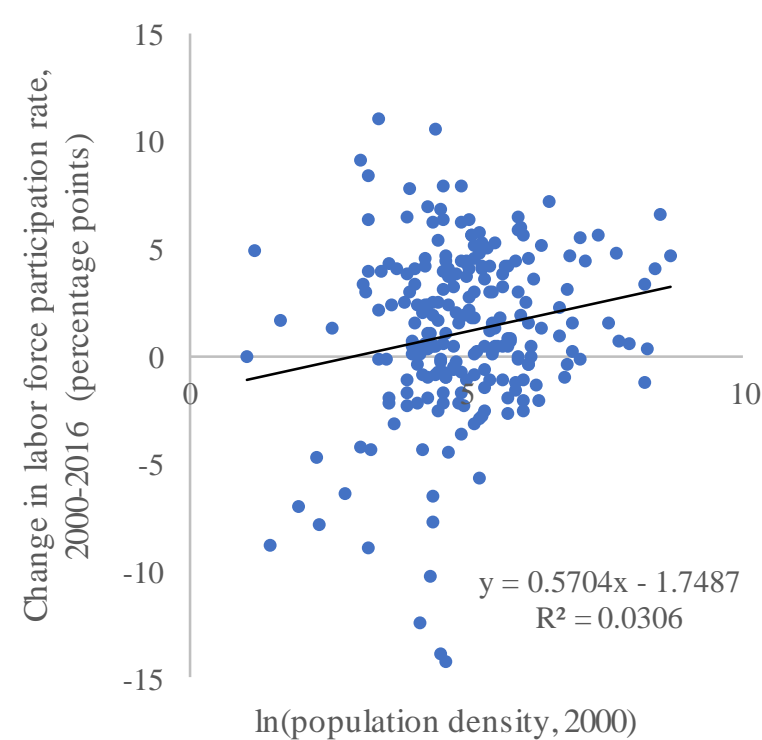

Sources: Eurostat; and authors' calculations.

Kingdom), with changes ranging from 6-9 percentage point increases (in parts of Spain and Germany) to 15-20 percentage point drops (in parts of Romania).

Labor force participation rates have, however, converged over time (Figure 5). Regions with relatively higher participation rates in 2000 experienced larger declines (or smaller increases) over the following period (for instance some regions in Norway), while regions with relatively lower participation rates in 2000 experienced larger increases or smaller decreases (for instance in Hungary and Spain). ${ }^{5}$

While some countries show similar patterns across regions (increases in all regions in Hungary, Spain and Sweden, drops in all regions in Greece, Norway and Romania), most larger European
Figure 8. Changes in Labor Force Participation Rates

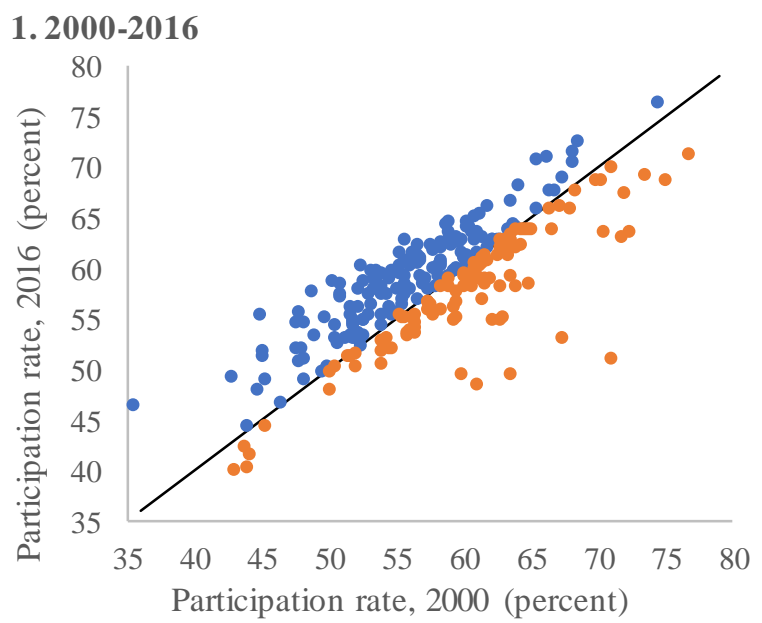

2. 2000-2008

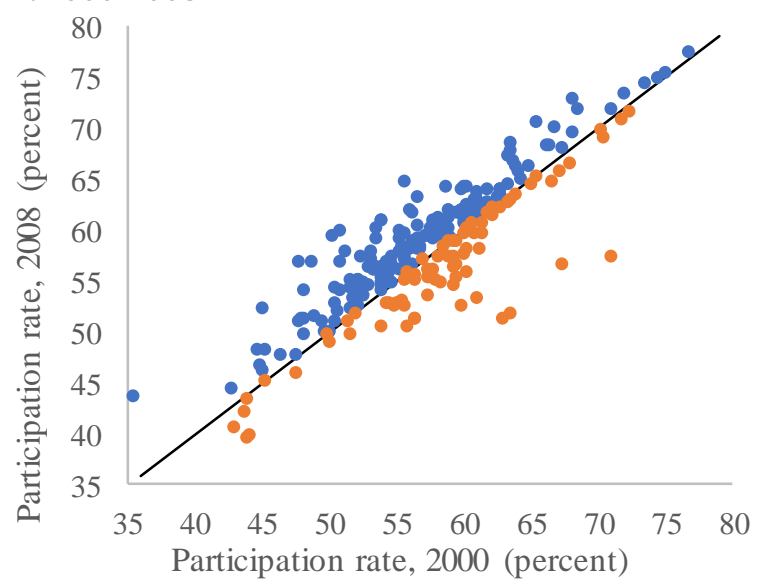

3. 2008-2016

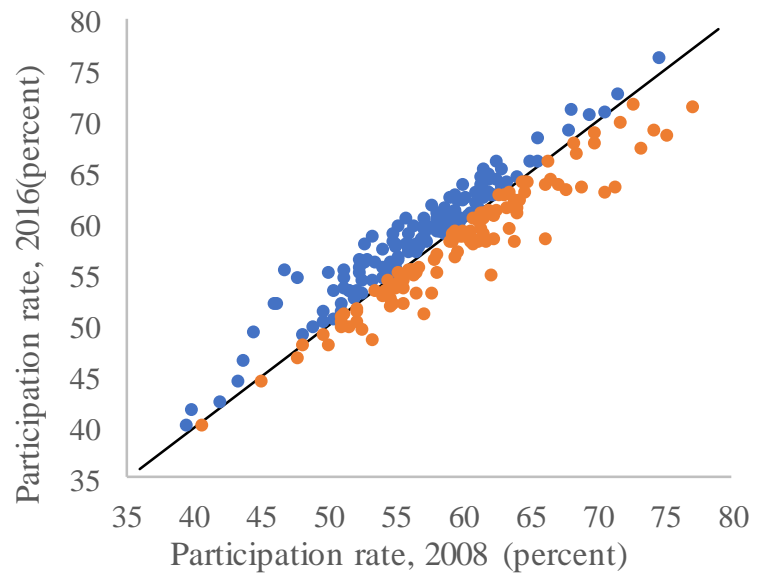

Sources: Eurostat; and authors' calculations.

\footnotetext{
${ }^{5}$ In addition to this convergence across countries, there appears to be also convergence within country as indicated by decreasing standard deviations of regions within a country over time.
} 
economies - among them Germany, France, Italy, Poland, and the United Kingdomexperienced significant within-country heterogeneity, with pronounced declines in some regions, and marked increases in others (Figure 6).

Initial population density appears to be positively correlated with changes in labor force participation (Figure 7). Participation rates increased more (or declined less) in urban regions, while they declined more (or increased less) in rural regions - a pattern similar to that observed in the United States (see Hilgenstock and Koczan 2018), though correlations are fairly low. ${ }^{6}$

Labor force participation rates increased in a majority (65 percent) of European regions over the period 20002016, with a median increase of 3 percentage points; the remaining 35 percent of regions exhibited a median decline of 1.7 percentage points (Figure 8, panel 1). While on average increases appear to be somewhat smaller, and declines more widespread after the Global Financial Crisis and during the European sovereign debt crisis (2008-2016) than in the pre-crisis period (2000-2008), this hides considerable heterogeneity in regions' experiences (Figure 8, panels 2 and 3). About a third of regions experienced a post-crisis decrease following a pre-crisis increase; 21 percent saw an increase in the post-crisis period after a decline in the precrisis period; 35 percent of regions saw increases in both periods and 11 percent saw decreases in both.

\section{Figure 9. Changes in Labor Market} Dynamics

(Percentage points)

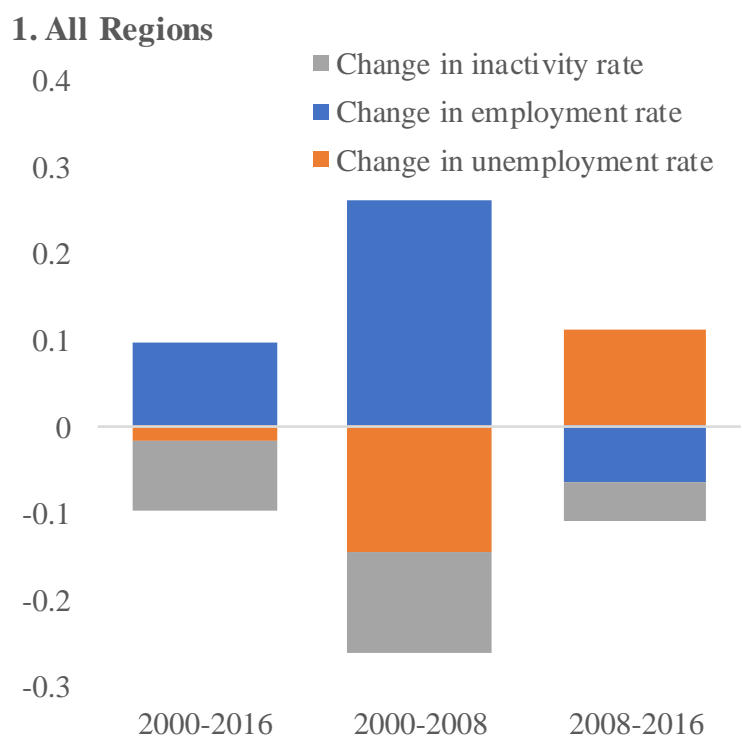

2. Regions by Population Density

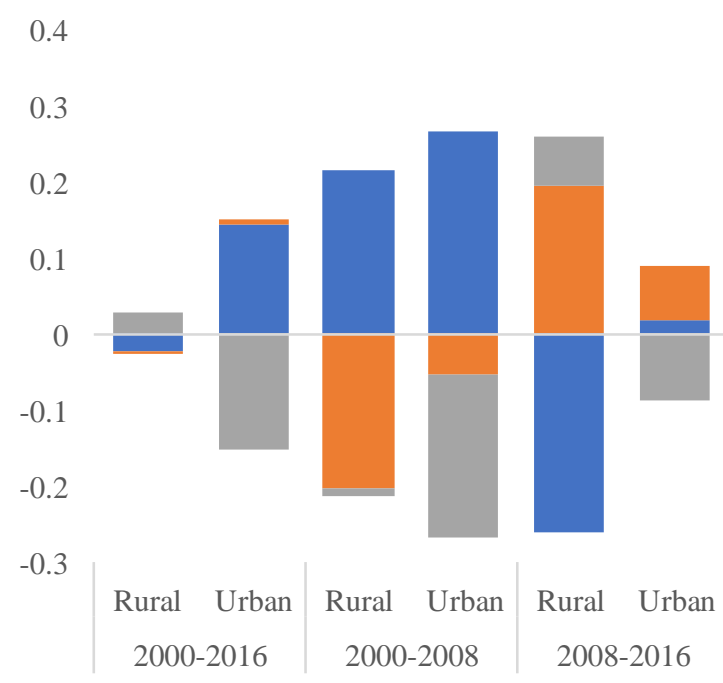

Sources: Eurostat; and authors' calculations. Note: Employment rate, unemployment rate, and inactivity rate area defined as total employment, total unemployment, and total inactive population as a percentage of total population, respectively. Rural regions are those below the 25th percentile of the population density distributionl; urban regions are those above the 75th percentile of the distribution.

\footnotetext{
${ }^{6}$ Participation is generally higher in urban areas as well.
} 
While on average there is no clear break in participation after the Global Financial Crisis, margins of labor market adjustment changed considerably (Figure 9). Over the full 2000-2016 period rising employment was matched almost one-for-one by rising participation, with very little change in unemployment. The pre-crisis period was characterized by flows from unemployment and inactivity into employment. Post-crisis, employment started to decline, matched almost fully by a rise in unemployment, with still small increases in participation.

These averages again hide interesting urban-rural differences (Figure 9, panel 2). Unemployment appears to exhibit much larger swings in rural than in urban areas: while rural regions saw a larger decline in unemployment in the pre-crisis period compared to urban regions, they also saw a much larger increase in unemployment in the post-crisis period. Correspondingly, pre-crisis flows consisted mostly of movements from unemployment to employment in rural areas, and from inactivity to employment in urban areas. Employment dropped much more sharply post-crisis in rural areas, translating into large increases in unemployment and some increases in inactivity. Urban areas saw some rise in unemployment as well, though in the context of (small) increases in employment and activity. ${ }^{7}$ Over the whole analysis period (2000-2016), urban regions still saw large increases in employment and activity, while rural areas saw small employment declines matched by moderate drops in activity.

\section{EMPIRICAL STRATEGY AND RESUltS}

This section examines the drivers of changes in participation rates at the regional level, looking at the effects of aging, cyclical factors, education, trade and technology. Furthermore, this section tests the effects of the two novel measures of local exposures to routinization and to offshoring described in Section III. ${ }^{8}$ The two measures are highly correlated, and most regions are relatively highly exposed to automation as well as offshoring (among them regions in Eastern France, Northern Italy, the Czech Republic, the Slovak Republic and Hungary - areas of 'old industry' as well as those integrated in the Central European supply chain), or neither highly exposed to automation nor to offshoring (more agricultural regions in Northern and Western Spain, Portugal, Poland, Romania, the Baltics, Greece and Finland). Some regions are, however, highly exposed to offshoring but not to automation (such as large parts of the United Kingdom, Southern France and Southern

\footnotetext{
${ }^{7}$ Pre-crisis increases and post-crisis declines in employment also characterized the most populous regions, though while unemployment increased in more than half post-crisis, participation only fell in the 10 regions (most of them in the South) with the most pronounced drops in employment (Annex Figure 1).

${ }^{8}$ Regional exposures cannot be constructed for Germany and the Netherlands due to data limitations, therefore, initial values in both cases are shown at the country level and regions from the two countries are excluded from the regression analysis.
} 
Figure 10. Exposures to Routinization and Offshoring, 2000

1. Exposure to Routinization (index)

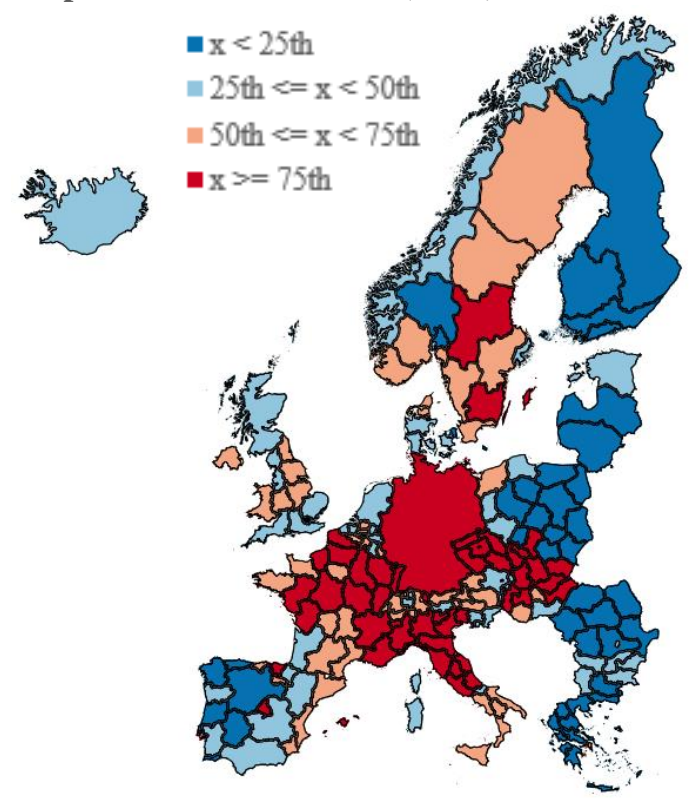

2. Exposure to Offshoring (index)

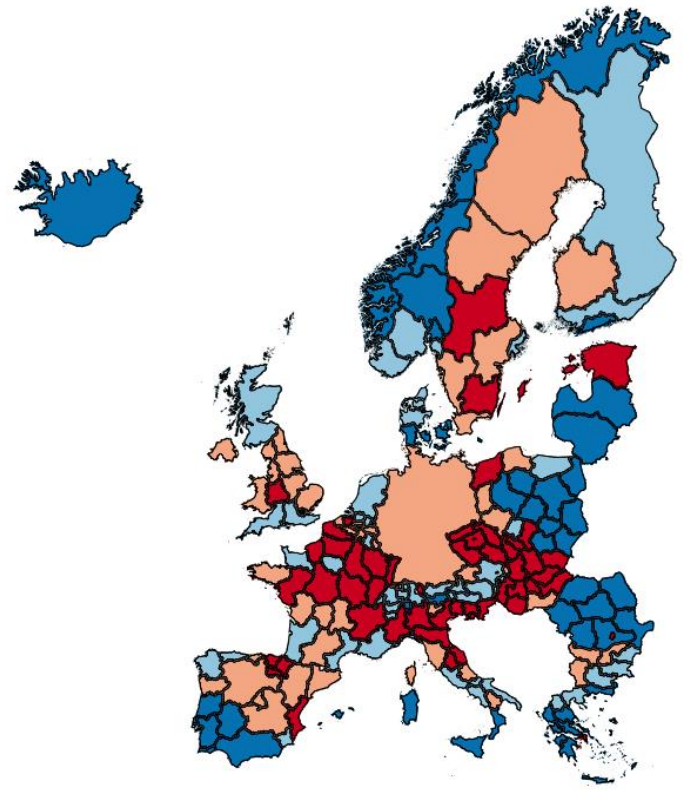

Sources: Eurostat, European Union Labour Force Survey; and authors' calculations.
Figure 11. Changes in Exposures to Routinization and Offshoring, 2000-2016

1. Change in Exposure to Routinization (index)

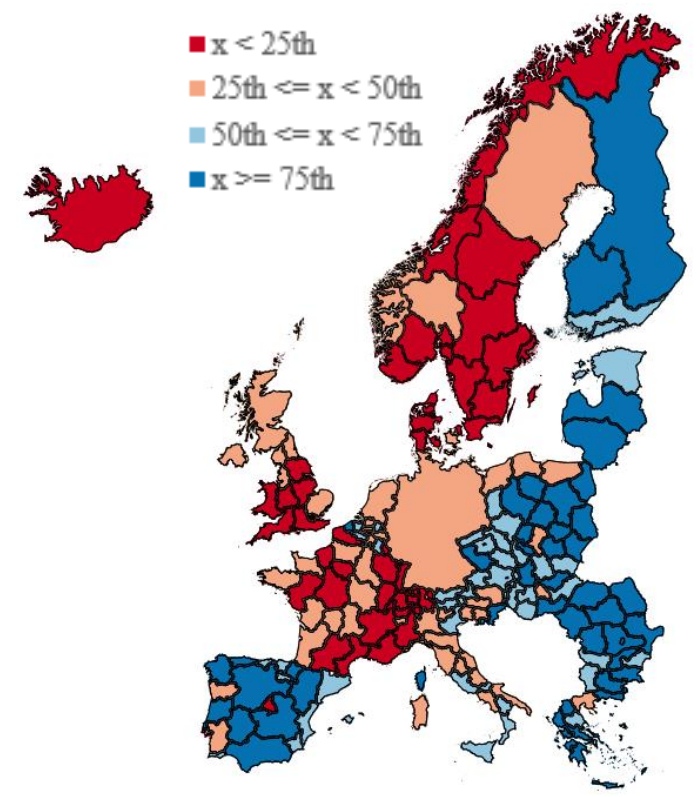

2. Change in Exposure to Offs horing (index)
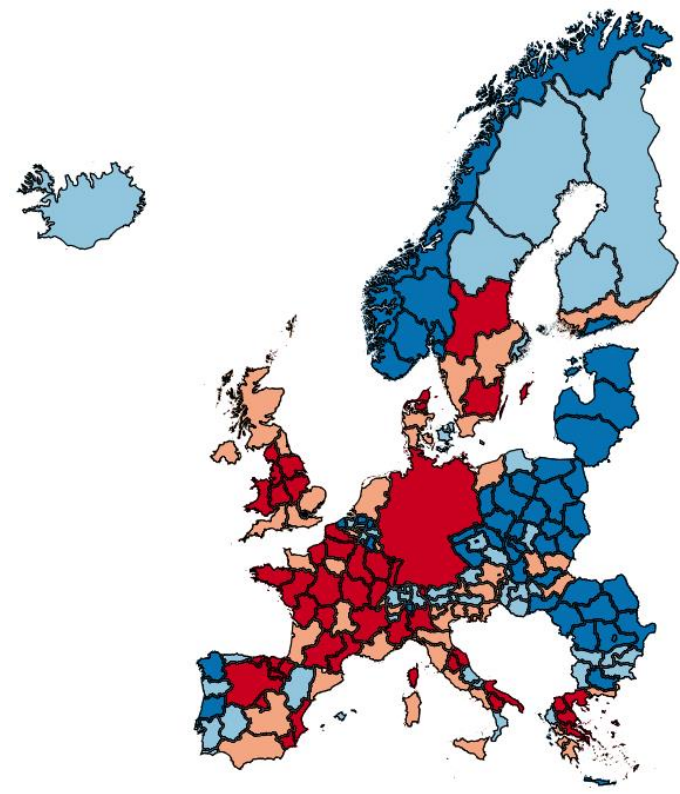

Sources: Eurostat, European Union Labour Force Survey; and authors' calculations.

Norway, which may be characterized by more labor-intensive industries), or in turn highly exposed to routinization but not to offshoring (regions in Austria, Denmark, Switzerland, which may have seen an earlier offshoring of jobs already in the pre-2000 period). Figure 11 shows changes in the exposures to routinization and offshoring between 2000 and 2016 and, together with Figure 12, 
illustrates the negative correlation between initial exposures and subsequent changes in exposures.

Zooming in on the link between these initial exposures to trade and technology and subsequent changes in participation, Figure 13 illustrates the strong positive correlations between the two exposure measures and changes in labor force participation. In Europe, unlike in the United States (see Hilgenstock and Koczan 2018), regions with higher initial exposures to automation and offshoring saw larger subsequent increases in participation (rather than detachment from the workforce as a result of trade- or technology-related dismissals). Figure 14 illustrates correlations between additional drivers of changes in labor force participation rates considered in the empirical analysis: cyclical factors, aging, and changes in educational attainment.

Building on these correlations, crosssectional regressions at the regional level examine the association between 2000-2016 changes in labor force participation rates and aging, cyclical conditions, education, as well as the impacts of initial exposures to routinization and offshoring. In particular, the following specification is estimated:

$$
\begin{aligned}
\Delta y_{i j}=\beta_{1} \Delta \text { dep } & \text { ratio }_{i j}+\beta_{2} \text { growth }_{i j} \\
& +\beta_{3} \Delta e d u c_{i j}+\beta_{4} \text { rout }_{i j}^{0} \\
& +\beta_{5} \text { offsh } \text { f }_{i j}^{0}+\alpha_{j}
\end{aligned}
$$

\section{Figure 12. Exposures to Routinization and Offshoring and Subsequent Changes in Exposures}

1. Exposure to Routinization

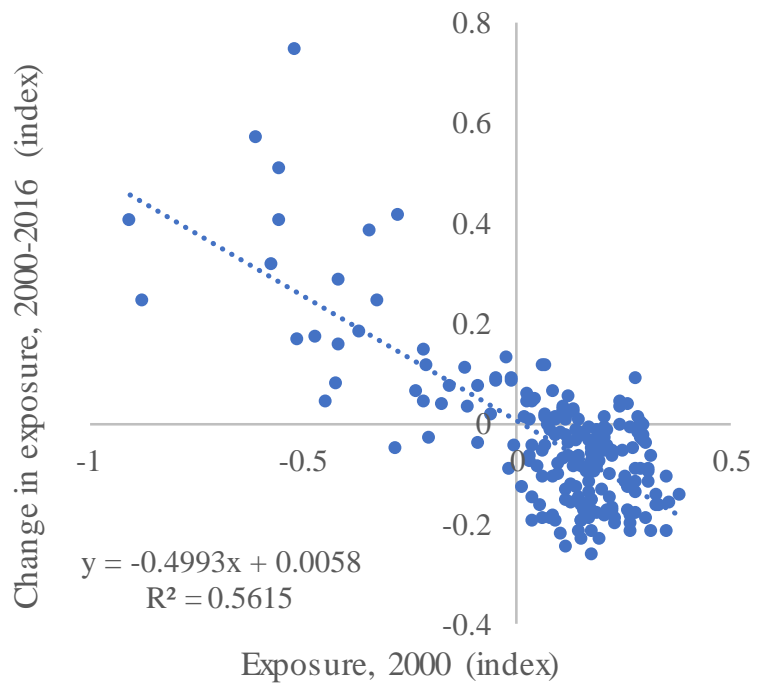

2. Exposure to Offshoring

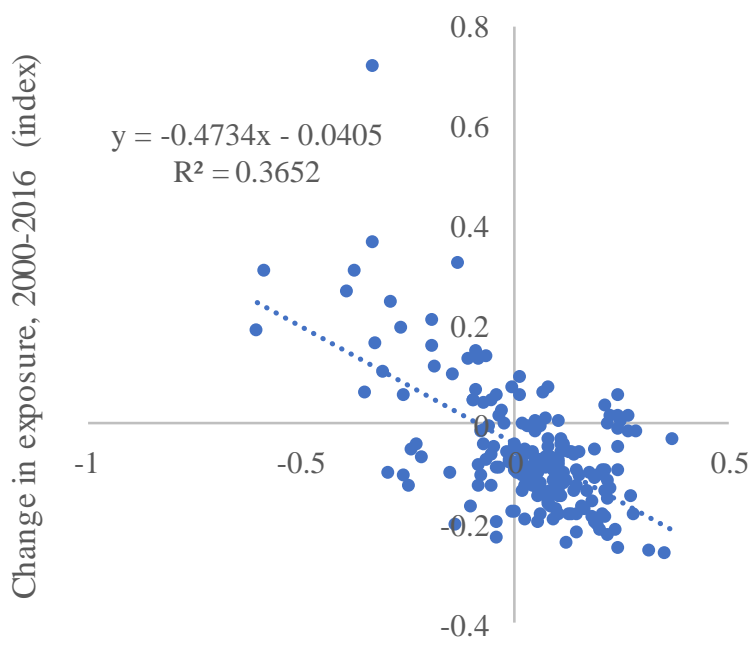

Exposure, 2000 (index)

Sources: Eurostat, European Union Labour Force Survey; and authors' calculations.

where $\Delta y_{i j}$ is the change in labor force participation between 2000 and 2016 in region $i$ country $j, \Delta$ dep ratio ${ }_{i j}$ is the change in the old-age dependency ratio (one possible proxy for aging), growth $h_{i j}$ is average real GDP growth and $\Delta e d u c_{i j}$ is the change in educational attainment. Initial exposures $\left(\right.$ rout $_{i j}^{0}$ and $\left.o f f s h_{i j}^{0}\right)$ are highly correlated and are thus included one at a time in the regressions. Specifications focus on long changes rather than annual data in order to allow for labor markets to adjust to shocks, examining if such shocks, including 
those from automation and/or offshoring, have lasting effects on participation. Regressions also control for time invariant country characteristics $\alpha_{j}$. Standard errors are adjusted for heteroskedasticity. ${ }^{9}$

The results point to significant effects of aging, cyclical conditions, and education on labor force participation (Table 1). Labor force participation declines were larger in regions, which experienced lower real GDP growth over this time period, although the coefficients are generally rather imprecisely estimated. Labor force participation declines were also larger in regions where the structure of population shifted more towards individuals older than 65 . The sensitivity of participation to aging appears to be higher in Europe than in the United States, possibly related to more generous pensions or more avenues to early retirement. Educational gains are also strongly correlated with increases in participation at the regional level, though the effect is somewhat weaker than in the United States.

Table 1. Drivers of Labor Force Participation Rates in European Regions

\begin{tabular}{|c|c|c|c|c|c|}
\hline Variables & (1) & (2) & (3) & (4) & (5) \\
\hline \multirow[t]{2}{*}{ Average Real GDP Growth } & & & -0.178 & -0.441 & -0.348 \\
\hline & & & $(0.240)$ & $(0.275)$ & $(0.277)$ \\
\hline \multirow[t]{2}{*}{ Change in Old-Age-Dependency Ratio } & & & $-0.275 * * *$ & $-0.288 * * *$ & $-0.295^{* * *} *$ \\
\hline & & & $(0.0627)$ & $(0.0824)$ & $(0.0844)$ \\
\hline \multirow{2}{*}{ Change in Postsecondary Share } & & & $0.256 * * *$ & $0.308 * * *$ & $0.282 * * *$ \\
\hline & & & $(0.0557)$ & $(0.0703)$ & (0.0716) \\
\hline \multirow[t]{2}{*}{ Initial Exposure to Routinization } & $6.544 * * *$ & & & $7.058 * * *$ & \\
\hline & (1.484) & & & (1.428) & \\
\hline \multirow[t]{2}{*}{ Initial Exposure to Offshoring } & & $6.770 * * *$ & & & $6.992 * * *$ \\
\hline & & (1.686) & & & (1.642) \\
\hline Observations & 185 & 185 & 262 & 177 & 176 \\
\hline$R^{2}$ & 0.698 & 0.693 & 0.680 & 0.751 & 0.741 \\
\hline
\end{tabular}

Source: Authors' calculations.

Note: Standard errors are in parentheses. The dependent variable is change in labor force participation rate. $* p<0.1 ; * * p<0.05 ; * * * p<0.01$.

In contrast to the findings of the literature on the United States and in line with the bivariate correlations above, the effects of trade and technology are positive: regions with higher initial exposures to automation and offshoring due their occupational employment compositions saw larger subsequent increases in participation rates, even controlling for other factors. This effect is robust to controlling for population density and the inclusion of country-level policies (such as spending on active labor market programs, union density or the generosity of unemployment benefits) instead of country fixed effects.

\footnotetext{
${ }^{9}$ Baseline results do not include measures of population growth and migration, however, results for a smaller subsample are robust to their inclusion.
} 
Figure 13. Drivers of Changes in Labor Force Participation Rates

1. Routine Exposure and Changes in Labor Force Participation

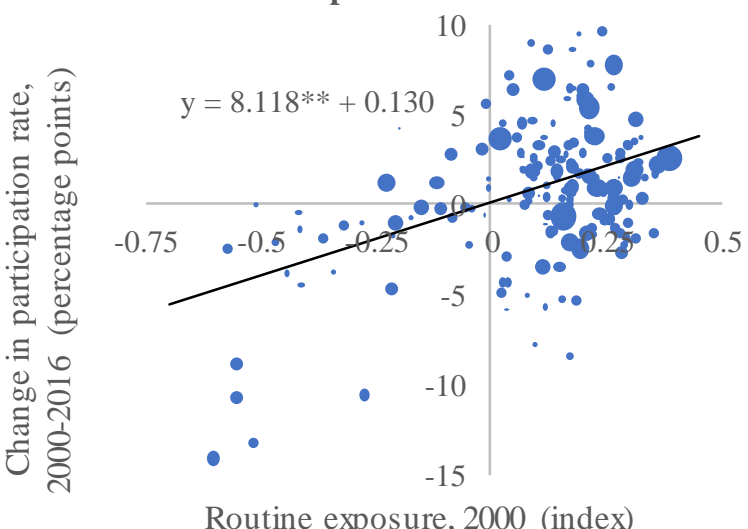

2. Offshoring Exposure and Changes in Labor Force Participation

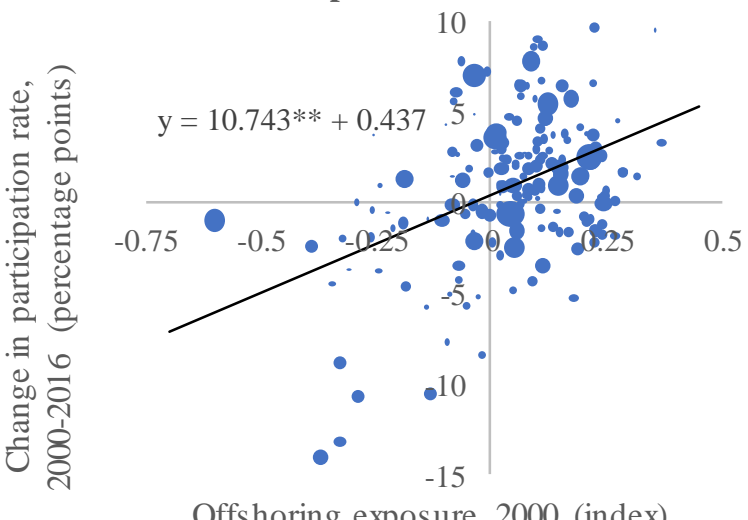

Sources: Eurostat, European Union Labor Force Survey; and authors' calculations.

Note: Marker size is based on 2016 total population. Trend lines represent results of population-weighted bivariate regressions.

There are several possible explanations for this finding. Compared to US metropolitan areas, European countries experienced smaller changes in the occupational mix over this time period, which suggests that fewer jobs were automated or offshored than in the United States. The positive correlation might also signal an added second worker effects, where households may add a second worker
Figure 14. Additional Drivers of Changes in Labor Force Participation Rates

1. Average Real GDP Growth and Changes in Labor Force Participation

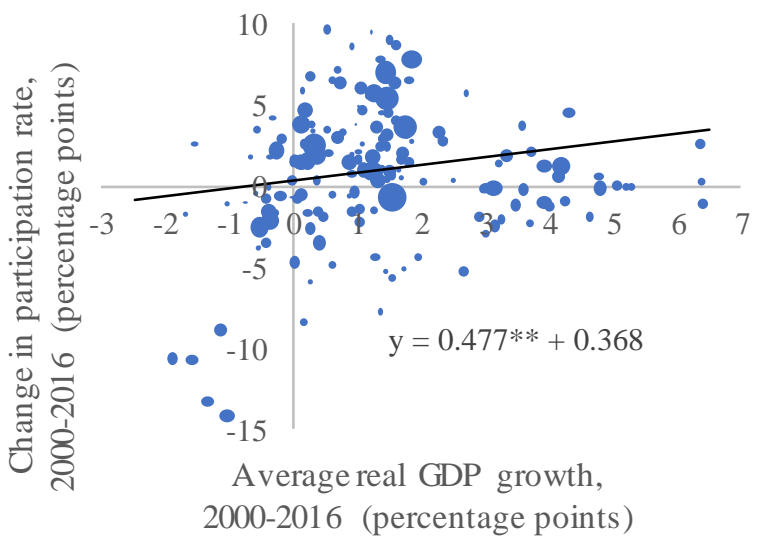

2. Changes in Dependency Ratio and Changes in Labor Force Participation

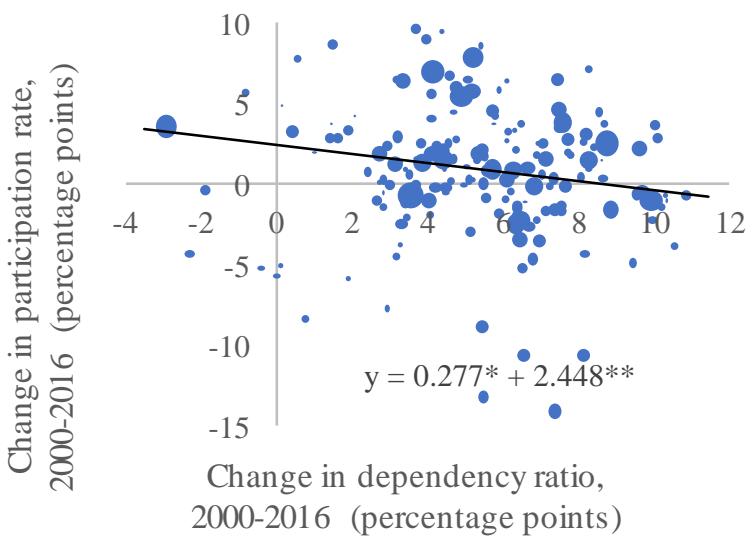

3. Changes in Tertiary Education and Changes in Labor Force Participation

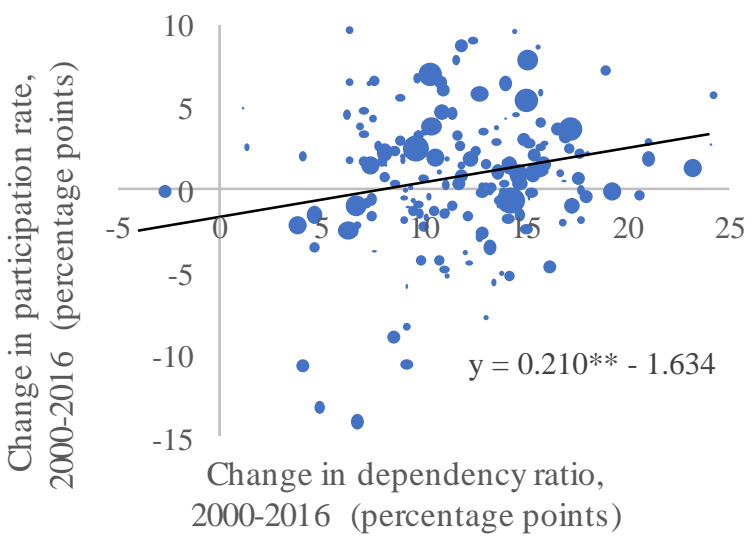

Sources: Eurostat; and authors' calculations. Note: Marker size is based on 2016 total population. Trend lines represent results of population-weighted bivariate regressions. 
Figure 15. Model Fit

1. Table 1, Column (4)

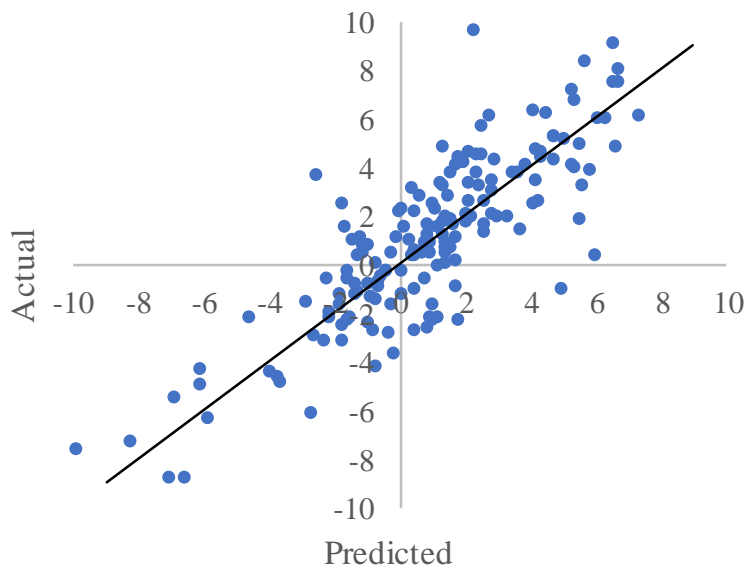

2. Table 1, Column (5)

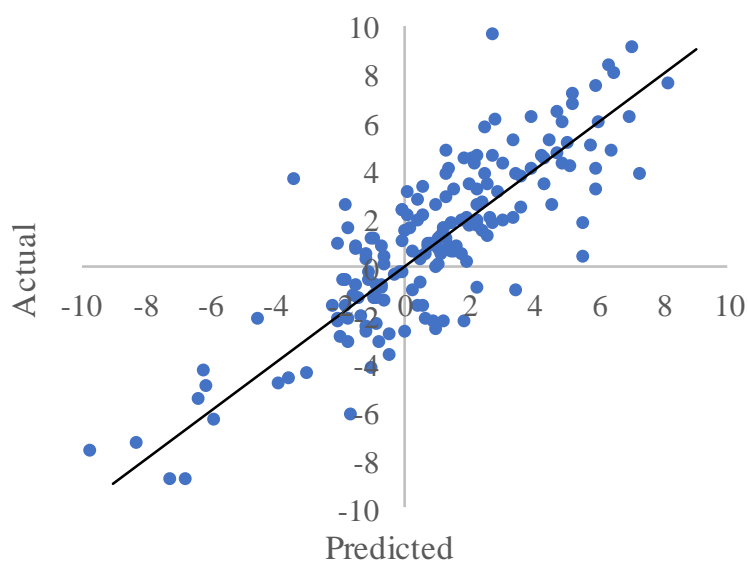

Source: Authors' calculations.

to make up for lost income of the first - a hypothesis discussed in greater detail in the following.

Figure 15 illustrates the fit of the regressions in Table 1, and Figure 16 shows the relative contributions of each of these factors to 2000-2016 changes in participation rates (the decompositions are based on columns 4 and 5 of Table 1). The decompositions point to significant drags from aging and cyclical factors, as well as time-invariant country characteristics. The most important contribution stems from changes in the share of the population with tertiary education. This component alone, driven by a striking 12 percentage point increase in the tertiary education share on average, would act to increase labor force participation by 3.3-3.6 percentage points, thereby more than offsetting the downward pressures resulting from aging and cyclical factors. This large effect of education is in line with the country-level findings in Chapter 3 of the April 2018 World Economic Outlook, and constitutes a further key difference between the evolution of participation in Europe versus the United States, where education increased earlier. 
While on average, the quantitative contribution of trade and technology on participation was relatively small (Figure 16), for some European regions the effects are quite substantial. In order to examine the regional patterns underlying the positive effects of trade and technology noted above, Figure 17 examines effects for regions with high and low initial exposures to routinization and offshoring, respectively. Regions with high initial exposures to routinization (above the $75^{\text {th }}$ percentile of the distribution, such as regions in France, Italy, and Hungary) experienced subsequent increases in labor force participation rates, while regions less exposed to routinization (below the $25^{\text {th }}$ percentile of the distribution, such as regions in Poland, and Romania) experienced declines (Figure 17, panel 1). Similar results emerge for offshoring: regions with high initial exposures to offshoring (above the $75^{\text {th }}$ percentile of the distribution, such as parts of the Czech Republic and Hungary) experienced increases in participation as they became more integrated in regional supply chains, while regions below the $25^{\text {th }}$ percentile of the exposure to offshoring distribution (agricultural regions with low routinization scores, as mentioned above) saw declines in participation (Figure 17, panel 2).

As discussed above, this points to still-positive effects of high initial exposures to routinization and offshoring in diverse urban regions (for instance London, Paris,
Figure 17. Contributions of Exposures to Routinization and Offshoring and Changes in Labor Force Participation Rates

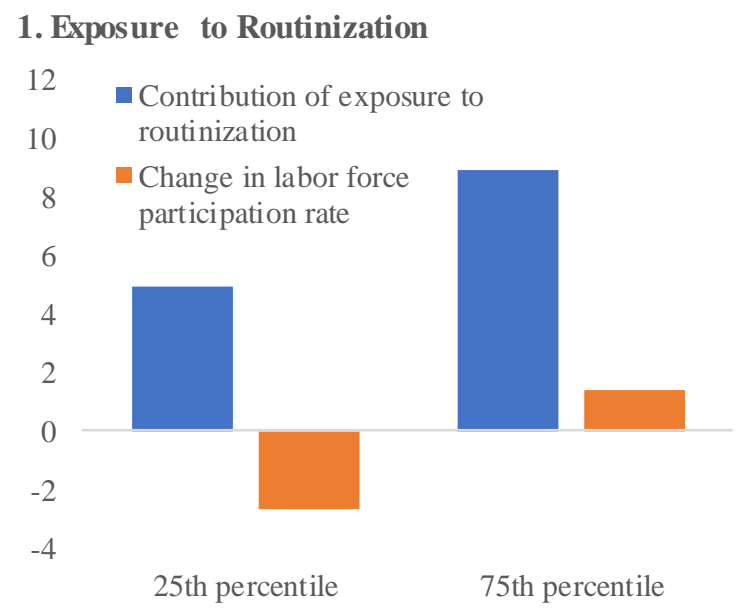

2. Exposure to Offshoring

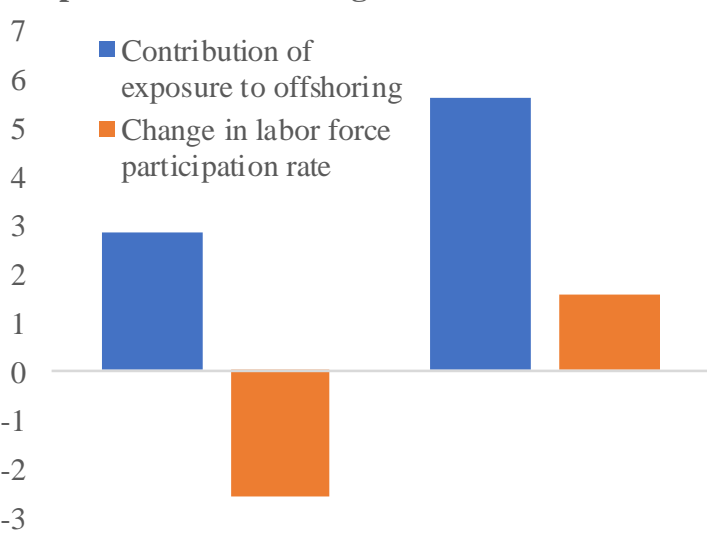

25th percentile 75th percentile

Sources: Authors' calculations.

Note: Bars in both panels show relative contributions of exposure to routinization and to offshoring respectively as well as changes in labor force participation rates for metropolitan areas below the 25 th percentile and above the 75 th percentile of the distribution regarding the respective exposure measure. Simple averages across metropolitan areas are shown.

Catalonia, Madrid), some 'old industrial regions' in advanced Europe (in Northern Italy, Sweden and Switzerland) ${ }^{10}$ and regions benefiting from offshoring and increased supply chain integration in emerging Europe (for instance in the Czech Republic and Hungary),

\footnotetext{
${ }^{10}$ Some regions with high initial exposures to routinization did experience drops in participation, for instance in Central France and Southern Italy.
} 
while other more sparsely populated, often more agricultural regions (in parts of Finland, Iceland, Norway, Romania, and Scotland) are lagging behind.

As noted above, the positive effects of initial exposures to routinization and offshoring on participation could be driven by an added second worker effect, where households may add a second worker to make up for lost income of the first. This would be consistent with the observed large increases in female participation in Europe, and could also explain differences relative to the United States, where female participation increased earlier and such gains are already plateauing. While testing this directly would require household-level data that allows us to match spouses, simple correlations suggest that female participation indeed increased more in regions that were initially more exposed to automation and offshoring, with strikingly strong correlations (Figure 18). ${ }^{11} 12$

\section{ConClusions}

This paper documented tremendous heterogeneity in the evolution of participation rates across European regions. As in the United States, declines in participation are more pronounced in rural regions, while urban areas generally still see rising participation. However, unlike in the United States, trade and technology are not associated

${ }^{11}$ While regions with higher initial exposures to routinization are also those with lower initial female participation and we could thus be picking up a convergence effect (lower initial female labor force participation associated with larger subsequent increases), the correlation between initial routinization and initial female participation is very weak (with an R-squared of around 3 percent). Some of this effect would likely be mopped up by the included country fixed effects.

${ }^{12}$ Gender-specific regressions in line with those in Table 1 confirm large positive effects of exposures to routinization and offshoring on women's participation. We do not control for changes in the opposite gender's participation directly - while at the individual level we might expect a negative correlation, at the regional level these would be highly positively correlated due to common local labor market effects.

\section{Figure 18. Exposures to Routinization and Offshoring and Change in Female Labor Force Participation}

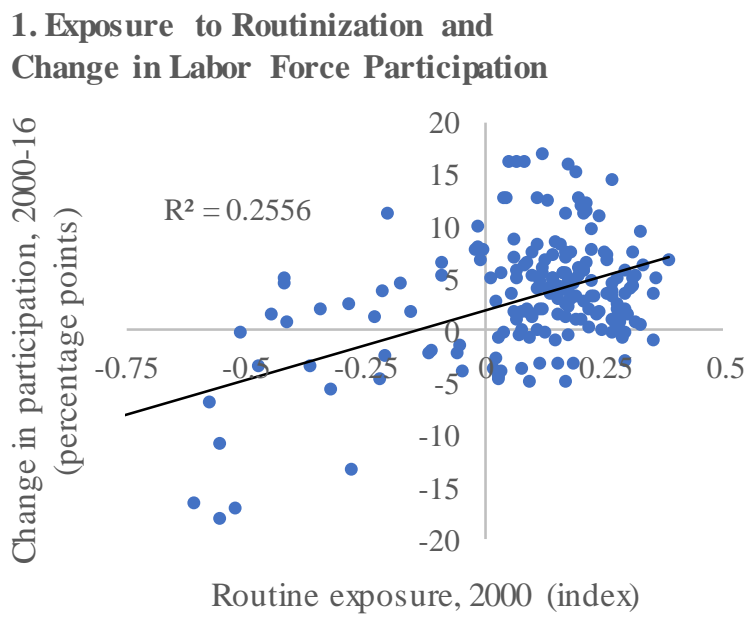

2. Exposure to Offshoring and Change in Labor Force Participation

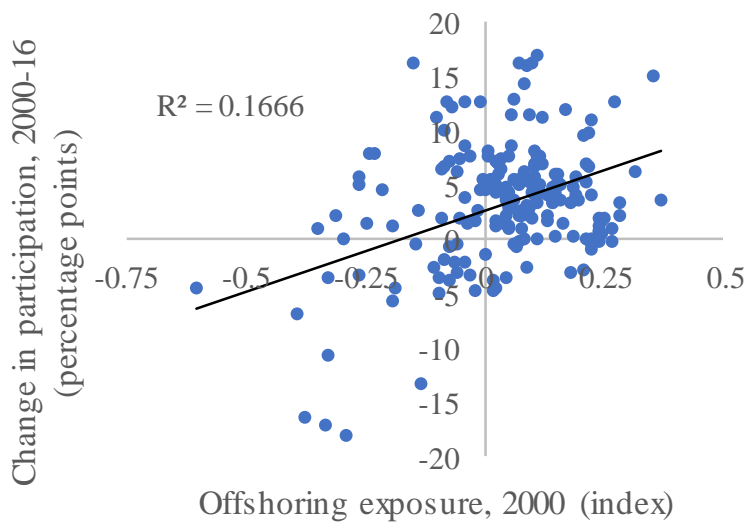

Sources: Euros tat, European Union Labour Force Survey; and authors' calculations. 
with displacement-regions with high initial exposures to routinization and offshoring, especially diverse cities, some 'old industrial regions', and those participating in the Central European supply chain benefited from these forces on average, likely driven by an added second worker effect, in line with the large increases in women's participation. Further work in this area would, however, be useful, relying on individual-level data to examine the second earner effect in greater detail.

Striking within-country differences in the evolution of labor force participation, however, have important implications for policy - they call for more explicit recognition of the spatial dimension of economic vulnerability given that short- and medium-term costs are concentrated not only in particular sectors and occupations but also affect different places in different ways. 


\section{REFERENCES}

Acemoglu, Daron, and Pascual Restrepo. 2017. "Robots and Jobs: Evidence from US Labor Markets.” NBER Working Paper 23285, National Bureau of Economic Research, Cambridge, MA.

Austin, Benjamin, Edward Glaeser and Lawrence H. Summers. 2018. "Saving the Heartland: Place-based Policies in $21^{\text {st }}$ Century America." Brookings Papers on Economic Activity Conference Drafts, March 8-9, 2018.

Autor, David H., and David Dorn. 2013. "The growth of low-skill service jobs and the polarization of the US labor market." American Economic Review 103 (5): 1553-97.

Autor, David H., David Dorn, and Gordon H. Hanson. 2016. "The China Shock: Learning from Labor-Market Adjustment to Large Changes in Trade." Annual Review of Economics 8: 205-40.

Balleer, Almut, Ramon Gómez-Salvador, and Jarkko Turunen. 2014. "Labor Force Participation across Europe: A Cohort-Based Analysis.” Empirical Economics 46: $1385-415$.

Blinder, Alan S., and Alan B. Krueger. 2013. "Alternative Measures of Offshorability: A Survey Approach.” Journal of Labor Economics 31 (1): 97-128.

Brooks, Robin, Nagle Peter and Jonathan Fortun. 2017. "Can the Labor Market Heal a Divided Nation?” IIF Global Macro Views, November 13.

Brooks, Robin, Nagle Peter and Jonathan Fortun. 2017. "Red versus Blue States in the Jobs Recovery” IIF Global Macro Views, November 15.

Brooks, Robin, Nagle Peter and Jonathan Fortun. 2017. "Why are Red State Labor Markets Lagging?” IIF Global Macro Views, November 21.

Council of Economic Advisers. 2016. "The Long-Term Decline in Prime-Age Male Labor Force Participation.” Washington, DC.

Christiansen, Lone Engbo, Huidan Lin, Joana Pereira, Petia Topalova and Rima Turk. 2016. "Individual Choice or Policies? Drivers of Female Employment in Europe" IMF Working Paper No. 16/49, International Monetary Fund, Washington, DC.

Cipollone, Angela, Eleonora Patacchini, and Giovanna Vallanti. 2013. "Women Labor Market Participation in Europe: Novel Evidence on Trends and Shaping Factors." IZA Discussion Paper 7710, IZA Institute of Labor Economics, Bonn, Germany. 
Das, Mitali, and Benjamin Hilgenstock. 2018. "The Exposure to Routinization: Labor Market Implications for Developed and Developing Economies."

Euwals, Rob, Marike Knoef, and Daniel van Vuuren. 2011. "The Trend in Female Labour Force Participation: What Can Be Expected for the Future?" Empirical Economics 40: 729-53.

Genre, Veronique, Ramon Gómez-Salvador, and Ana Lamo. 2010. "European Women: Why Do(n’t) They Work?” Applied Economics 42 (12): 1499-514.

Goos, Maarten, Alan Manning, and Anna Salomons. 2014. "Explaining Job Polarization: Routine-Biased Technological Change and Offshoring." The American Economic Review 104 (8): 2509-26.

Graetz, Georg and Guy Michaels. 2015. "Robots at Work" CEP Discussion Paper No. 1335, Centre for Economic Performance, LSE.

Gregory, Terry, Anna Salomons, and Ulrich Zierahn. 2016. "Racing with or against the Machine? Evidence from Europe” ZEW Discussion Paper No. 16-053.Hilgenstock, Benjamin and Zsoka Koczan. 2018. "Permanently Displaced? Increasingly Disconnected? Labor Force Participation in U.S. States and Metropolitan Areas” IMF Working Paper.

International Monetary Fund. 2017. "Understanding the Downward Trend in Labor Income Shares." Chapter 3 of the World Economic Outlook. Washington, DC, April.

International Monetary Fund. 2018. "Labor Force Participation in Advanced Economies: Drivers and Prospects.” Chapter 2 of the World Economic Outlook. Washington, DC, April.

Krause, Eleanor, and Isabel Sawhill. 2017. "What We Know and Don't Know about Declining Labor Force Participation: A Review." Center on Children and Families, Brookings Institution, Washington, DC.

Miani, Céline and Stijn Hoorens. 2014. "Parents at work: Men and women participating in the labor force." European Commission Directorate General- Justice and Fundamental Rights Short Statistical Report No. 2.

Thévenon, Olivier. 2013. "Drivers of Female Labour Force Participation in the OECD." OECD Social, Employment and Migration Working Paper 145, Organisation for Economic Co-operation and Development, Paris. 


\section{Appendix Figure 1. Changes in Labor Market Dynamics, Individual Regions}

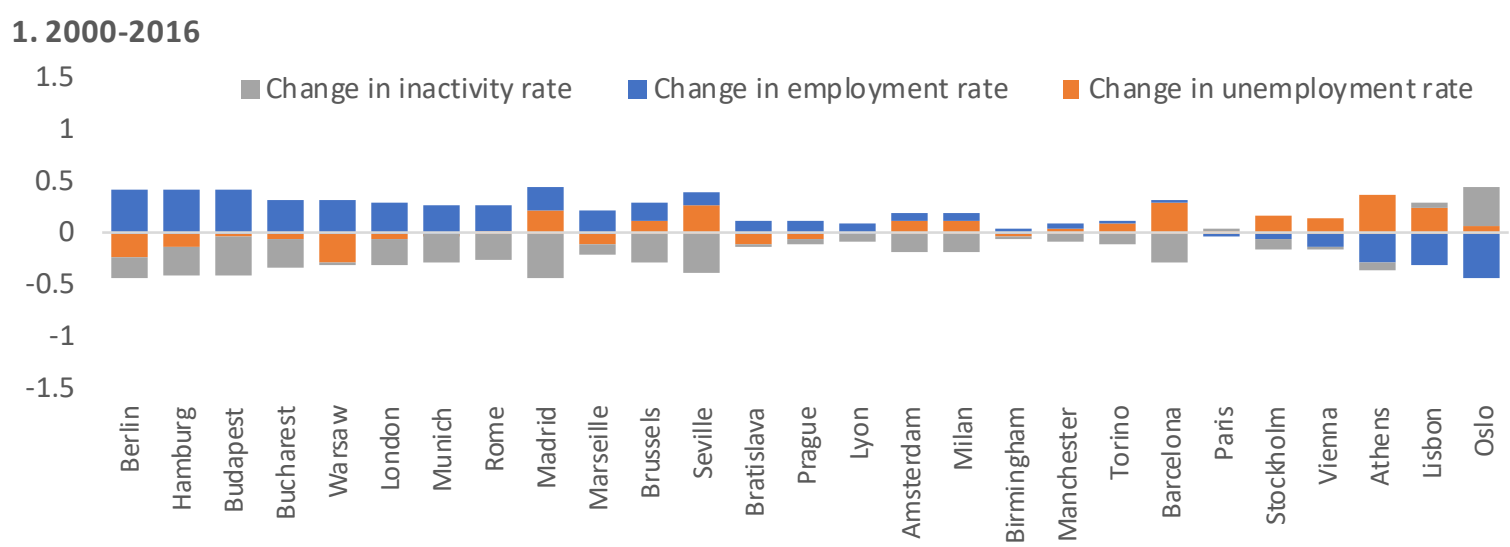

2. 2000-2008

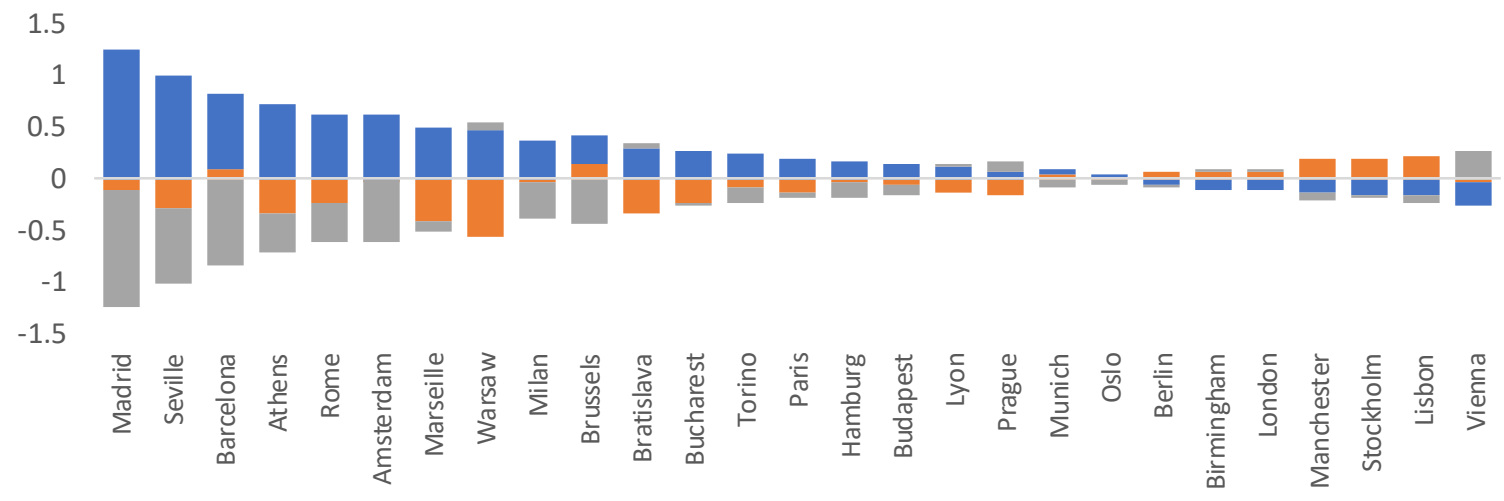

3. 2008-2016

1.5

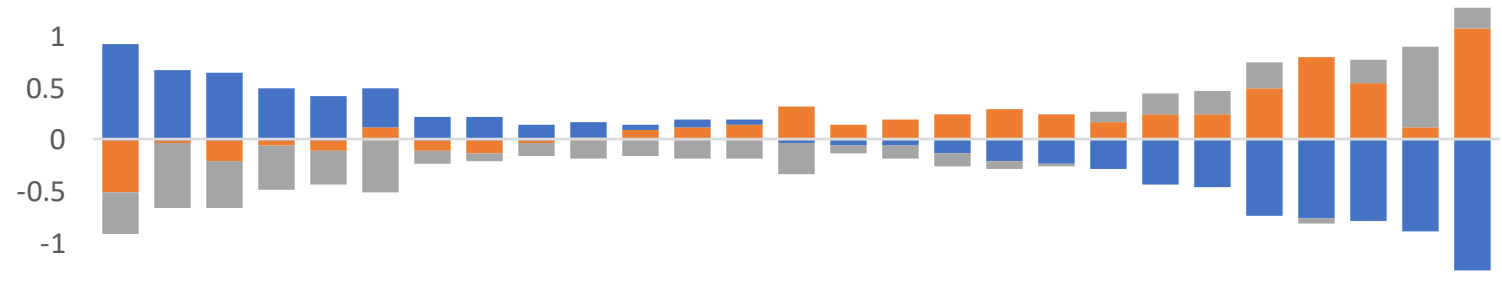

$-1.5$

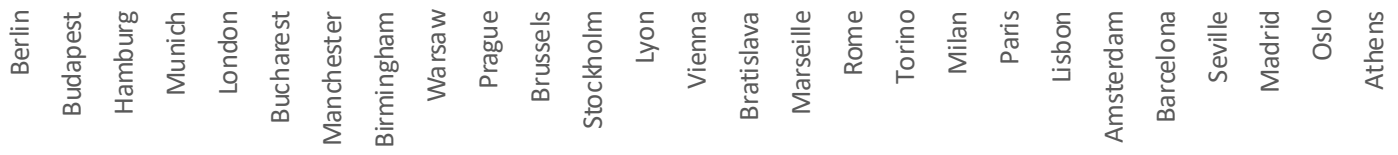

Sources: Eurostat; and authors' calculations.

Note: Employment rate, unemployment rate, and inactivity rate area defined as total employment, total unemployment, and total inactive population as a percentage of total population, respectively. 
Appendix Table 1. NUTS Regions

\begin{tabular}{ll} 
Code & Name \\
Austria & (AUT) \\
AT1 & Ostösterreich \\
AT11 & Burgenland (AT) \\
AT12 & Niederösterreich \\
AT13 & Wien \\
AT2 & Südösterreich \\
AT21 & Kärnten \\
AT22 & Steiermark \\
AT3 & Westösterreich \\
AT31 & Oberösterreich \\
AT32 & Salzburg \\
AT33 & Tirol \\
AT34 & Vorarlberg \\
Belgium & (BEL) \\
BE1 & Région de Bruxelles-Capitale \\
BE2 & Vlaams Gewest \\
BE21 & Prov. Antwerpen \\
BE22 & Prov. Limburg (BE) \\
BE23 & Prov. Oost-Vlaanderen \\
BE24 & Prov. Vlaams-Brabant \\
BE25 & Prov. West-Vlaanderen \\
BE3 & Région wallonne \\
BE31 & Prov. Brabant Wallon \\
BE32 & Prov. Hainaut \\
BE33 & Prov. Liège \\
BE34 & Prov. Luxembourg (BE) \\
BE35 & Prov. Namur \\
Bulgaria & (BGD) \\
BG3 & Severna i yugoiztochna Bulgaria \\
BG31 & Severozapaden \\
BG32 & Severen tsentralen \\
BG33 & Severoiztochen \\
BG34 & Yugoiztochen \\
BG4 & Yugozapadna i yuzhna tsentralna Bulgaria \\
BG41 & Yugozapaden \\
BG42 & Yuzhen tsentralen \\
Switzerland $($ CHE) \\
CH1 & Région lémanique \\
CH2 & Espace Mittelland \\
CH3 & Nordwestschweiz \\
CH4 & Zürich \\
CH5 & Ostschweiz \\
CH6 & Zentralschweiz \\
CH7 & Ticino \\
CZ1 & Praha \\
Czech & Republic (CZE) \\
CZ2 & StredníCechy \\
CZ3 & Jihozápad \\
CZ4 & Severozápad \\
CZ5 & Severovýchod \\
CZ6 & Jihovýchod \\
CZ7 & Strední Morava \\
CZ8 & Moravskoslezsko \\
Germany (DEU) \\
DE1 & Baden-Württemberg \\
DE11 & Stuttgart \\
DE12 & Karlsruhe \\
DE13 & Freiburg \\
DE14 & Tübingen \\
DE2 & Bayern \\
DE21 & Oberbayern \\
DE22 & Niederbayern \\
DE23 & Oberpfalz \\
DE24 & Oberfranken \\
DE25 & Mittelfranken \\
DE26 & Unterfranken \\
DE27 & Schwaben \\
\multicolumn{1}{|c|}{} & \\
\hline
\end{tabular}

\begin{tabular}{|c|c|c|c|}
\hline \multirow[t]{2}{*}{ Level } & Code & Name & Level \\
\hline & DE3 & Berlin & 1 \\
\hline 1 & DE4 & Brandenburg & 1 \\
\hline 2 & DE5 & Bremen & 1 \\
\hline 2 & DE6 & Hamburg & 1 \\
\hline 2 & DE7 & Hessen & 1 \\
\hline 1 & DE71 & Darmstadt & 2 \\
\hline 2 & DE72 & Gießen & 2 \\
\hline 2 & DE73 & Kassel & 2 \\
\hline 1 & DE8 & Mecklenburg-Vorpommern & 1 \\
\hline 2 & DE9 & Niedersachsen & 1 \\
\hline 2 & DE91 & Braunschweig & 2 \\
\hline 2 & DE92 & Hannover & 2 \\
\hline \multirow[t]{2}{*}{2} & DE93 & Lüneburg & 2 \\
\hline & DE94 & Weser-Ems & 2 \\
\hline 1 & DEA & Nordrhein-Westfalen & 1 \\
\hline 1 & DEA1 & Düsseldorf & 2 \\
\hline 2 & DEA2 & Köln & 2 \\
\hline 2 & DEA3 & Münster & 2 \\
\hline 2 & DEA4 & Detmold & 2 \\
\hline 2 & DEA5 & Arnsberg & 2 \\
\hline 2 & DEB & Rheinland-Pfalz & 1 \\
\hline 1 & DEB1 & Koblenz & 2 \\
\hline 2 & DEB2 & Trier & 2 \\
\hline 2 & DEB3 & Rheinhessen-Pfalz & 2 \\
\hline 2 & DEC & Saarland & 1 \\
\hline 2 & DED & Sachsen & 1 \\
\hline \multirow[t]{2}{*}{2} & DED2 & Dresden & 2 \\
\hline & DED3 & Leipzig & 2 \\
\hline 1 & DED4 & Chemnitz & 2 \\
\hline 2 & DEE & Sachsen-Anhalt & 1 \\
\hline 2 & DEF & Schleswig-Holstein & 1 \\
\hline 2 & DEG & Thüringen & 1 \\
\hline 2 & \multicolumn{3}{|c|}{ Denmark (DNK) } \\
\hline 1 & DK1 & Hovedstaden & 2 \\
\hline 2 & DK2 & Sjælland & 2 \\
\hline \multirow[t]{2}{*}{2} & DK3 & Syddanmark & 2 \\
\hline & DK4 & Midtjylland & 2 \\
\hline 2 & DK5 & Nordjylland & 2 \\
\hline 2 & \multicolumn{3}{|c|}{ Spain $(E S P)$} \\
\hline 2 & ES1 & Noroeste (ES) & 1 \\
\hline 2 & ES1 1 & Galicia & 2 \\
\hline 2 & ES12 & Principado de Asturias & 2 \\
\hline 2 & ES13 & Cantabria & 2 \\
\hline 2 & ES2 & Noreste (ES) & 1 \\
\hline \multirow[t]{2}{*}{2} & ES21 & País Vasco & 2 \\
\hline & ES22 & Comunidad Foral de Navarra & 2 \\
\hline 2 & ES23 & La Rioja & 2 \\
\hline 2 & ES24 & Aragón & 2 \\
\hline 2 & ES3 & Comunidad de Madrid & 1 \\
\hline 2 & ES4 & Centro (ES) & 1 \\
\hline 2 & ES41 & Castilla y León & 2 \\
\hline 2 & ES42 & Castilla-la Mancha & 2 \\
\hline \multirow[t]{2}{*}{2} & ES43 & Extremadura & 2 \\
\hline & ES5 & Este (ES) & 1 \\
\hline 1 & ES51 & Cataluña & 2 \\
\hline 2 & ES52 & Comunidad Valenciana & 2 \\
\hline 2 & ES53 & Illes Balears & 2 \\
\hline 2 & ES6 & Sur (ES) & 1 \\
\hline 2 & ES61 & Andalucía & 2 \\
\hline 1 & ES62 & Región de Murcia & 2 \\
\hline 2 & ES63 & Ciudad Autónoma de Ceuta (ES) & 2 \\
\hline 2 & ES64 & Ciudad Autónoma de Melilla (ES) & 2 \\
\hline 2 & ES7 & Canarias (ES) & 1 \\
\hline 2 & \multicolumn{3}{|c|}{ Finland (FIN) } \\
\hline 2 & FI1 & Manner-Suomi & 1 \\
\hline 2 & FI13 & Pohjois- ja Itä-Suomi & 2 \\
\hline 2 & FI18 & Etelä-Suomi & 2 \\
\hline
\end{tabular}


Appendix Table 1 (continued). NUTS Regions

\begin{tabular}{|c|c|}
\hline Code & Name \\
\hline FI181 & Helsinki-Uusimaa \\
\hline FI19 & Länsi-Suomi \\
\hline FI2 & Ăland \\
\hline \multicolumn{2}{|c|}{ France $($ FRA $)$} \\
\hline FR1 & Île de France \\
\hline FR2 & Bassin Parisien \\
\hline FR21 & Champagne-Ardenne \\
\hline FR22 & Picardie \\
\hline FR23 & Haute-Normandie \\
\hline FR24 & Centre (FR) \\
\hline FR25 & Basse-Normandie \\
\hline FR26 & Bourgogne \\
\hline FR3 & Nord - Pas-de-Calais \\
\hline FR4 & Est (FR) \\
\hline FR41 & Lorraine \\
\hline FR42 & Alsace \\
\hline FR43 & Franche-Comté \\
\hline FR5 & Ouest (FR) \\
\hline FR51 & Pays de la Loire \\
\hline FR52 & Bretagne \\
\hline FR53 & Poitou-Charentes \\
\hline FR6 & Sud-Ouest (FR) \\
\hline FR61 & Aquitaine \\
\hline FR62 & Midi-Pyrénées \\
\hline FR63 & Limousin \\
\hline FR7 & Centre-Est (FR) \\
\hline FR71 & Rhône-Alpes \\
\hline FR72 & Auvergne \\
\hline FR8 & Méditerranée \\
\hline FR81 & Languedoc-Roussillon \\
\hline FR82 & Provence-Alpes-Côte d'Azur \\
\hline FR83 & Corse \\
\hline FR9 & Départements d'outre-mer \\
\hline FR91 & Guadeloupe \\
\hline FR92 & Martinique \\
\hline FR93 & Guyane \\
\hline FR94 & La Réunion \\
\hline FRA50 & Mayotte \\
\hline \multicolumn{2}{|c|}{ Greece (GRC) } \\
\hline GR1 & Voreia Ellada \\
\hline GR11 & Anatoliki Makedonia, Thraki \\
\hline GR12 & Kentriki Makedonia \\
\hline GR13 & Dytiki Makedonia \\
\hline GR14 & Thessalia \\
\hline GR2 & Kentriki Ellada \\
\hline GR21 & Ipeiros \\
\hline GR22 & Ionia Nisia \\
\hline GR23 & Dytiki Ellada \\
\hline GR24 & Sterea Ellada \\
\hline GR25 & Peloponnisos \\
\hline GR3 & Attiki \\
\hline GR4 & Nisia Aigaiou, Kriti \\
\hline GR41 & Voreio Aigaio \\
\hline GR42 & Notio Aigaio \\
\hline GR43 & Kriti \\
\hline \multicolumn{2}{|c|}{ Croatia (HRV) } \\
\hline HR03 & Jadranska Hrvatska \\
\hline HR04 & Kontinentalna Hrvatska \\
\hline \multicolumn{2}{|c|}{ Hungary $(H U N)$} \\
\hline HU1 & Közép-Magyarország \\
\hline HU2 & Dunántúl \\
\hline HU21 & Közép-Dunántúl \\
\hline HU22 & Nyugat-Dunántúl \\
\hline HU23 & Dél-Dunántúl \\
\hline HU3 & Alföld és Észak \\
\hline HU31 & Észak-Magyarország \\
\hline HU32 & Észak-Alföld \\
\hline
\end{tabular}

\begin{tabular}{|c|c|c|}
\hline Level & Code & Name \\
\hline 3 & HU33 & Dél-Alföld \\
\hline 2 & \multicolumn{2}{|c|}{ Ireland $(I R L)$} \\
\hline \multirow[t]{2}{*}{1} & IE1 & Border, Midland and Western \\
\hline & IE2 & Southern and Eastern \\
\hline 2 & \multicolumn{2}{|c|}{ Italy $($ ITA $)$} \\
\hline 1 & ITC & Nord-Ovest \\
\hline 2 & ITC1 & Piemonte \\
\hline 2 & ITC2 & Valle d'Aosta/Vallée d'Aoste \\
\hline 2 & ITC3 & Liguria \\
\hline 2 & ITC4 & Lombardia \\
\hline 2 & ITF & Sud \\
\hline 2 & ITF1 & Abruzzo \\
\hline 2 & ITF2 & Molise \\
\hline 1 & ITF3 & Campania \\
\hline 2 & ITF4 & Puglia \\
\hline 2 & ITF5 & Basilicata \\
\hline 2 & ITF6 & Calabria \\
\hline 1 & ITG & Isole \\
\hline 2 & ITG1 & Sicilia \\
\hline 2 & ITG2 & Sardegna \\
\hline 2 & ITH1 & Provincia Autonoma di Bolzano/Bozen \\
\hline 1 & ITH2 & Provincia Autonoma di Trento \\
\hline 2 & ITH3 & Veneto \\
\hline 2 & ITH4 & Friuli-Venezia Giulia \\
\hline 2 & ITH5 & Emilia-Romagna \\
\hline 1 & ITI & Centro (IT) \\
\hline 2 & ITI1 & Toscana \\
\hline 2 & ITI2 & Umbria \\
\hline 1 & ITI3 & Marche \\
\hline 2 & ITI4 & Lazio \\
\hline 2 & \multicolumn{2}{|c|}{ Netherlands (NLD) } \\
\hline 2 & NL1 & Noord-Nederland \\
\hline 1 & NL11 & Groningen \\
\hline 2 & NL12 & Friesland (NL) \\
\hline 2 & NL13 & Drenthe \\
\hline 2 & NL2 & Oost-Nederland \\
\hline 2 & NL21 & Overijssel \\
\hline \multirow[t]{2}{*}{3} & NL22 & Gelderland \\
\hline & NL23 & Flevoland \\
\hline 1 & NL3 & West-Nederland \\
\hline 2 & NL31 & Utrecht \\
\hline 2 & NL32 & Noord-Holland \\
\hline 2 & NL33 & Zuid-Holland \\
\hline 2 & NL34 & Zeeland \\
\hline 1 & NL4 & Zuid-Nederland \\
\hline 2 & NL41 & Noord-Brabant \\
\hline 2 & NL42 & Limburg (NL) \\
\hline 2 & \multicolumn{2}{|c|}{ Norway (NOR) } \\
\hline 2 & NO1 & Oslo og Akershus \\
\hline 2 & $\mathrm{NO} 2$ & Hedmark og Oppland \\
\hline 1 & $\mathrm{NO} 3$ & Sør-Østlandet \\
\hline 1 & NO4 & Agder og Rogaland \\
\hline 2 & NO5 & Vestlandet \\
\hline 2 & NO6 & Trøndelag \\
\hline \multirow[t]{2}{*}{2} & NO7 & Nord-Norge \\
\hline & \multicolumn{2}{|c|}{ Poland (POL) } \\
\hline 2 & PL1 & Region Centralny \\
\hline \multirow[t]{2}{*}{2} & PL11 & Lódzkie \\
\hline & PL12 & Mazowieckie \\
\hline 2 & PL2 & Region Poludniowy \\
\hline 1 & PL21 & Malopolskie \\
\hline 2 & PL22 & Slaskie \\
\hline 2 & PL3 & Region Wschodni \\
\hline 2 & PL31 & Lubelskie \\
\hline 1 & PL32 & Podkarpackie \\
\hline 2 & PL33 & Swietokrzyskie \\
\hline 2 & PL34 & Podlaskie \\
\hline
\end{tabular}

Level

2

1

2

2

2

1

2

2

2

2

2

1

2

2

2

2

2 
Appendix Table 1 (continued). NUTS Regions

\begin{tabular}{|c|c|c|}
\hline Code & Name & Level \\
\hline PL4 & Region Pólnocno-Zachodni & \\
\hline PL41 & Wielkopolskie & \\
\hline PL42 & Zachodniopomorskie & \\
\hline PL43 & Lubuskie & \\
\hline PL5 & Region Poludniowo-Zachodni & \\
\hline PL51 & Dolnoslaskie & \\
\hline PL52 & Opolskie & \\
\hline PL6 & Region Pólnocny & \\
\hline PL61 & Kujawsko-Pomorskie & \\
\hline PL62 & Warminsko-Mazurskie & \\
\hline PL63 & Pomorskie & \\
\hline \multicolumn{3}{|c|}{ Portugal (PRT) } \\
\hline PT 1 & Continente & \\
\hline PT11 & Norte & \\
\hline PT 15 & Algarve & \\
\hline PT 16 & Centro (PT) & \\
\hline PT 17 & Área Metropolitana de Lisboa & \\
\hline PT 18 & Alentejo & \\
\hline PT2 & Região Autónoma dos Açores (PT) & \\
\hline PT3 & Região Autónoma da Madeira (PT) & \\
\hline \multicolumn{3}{|c|}{ Romania $($ ROU $)$} \\
\hline RO1 & Macroregiunea unu & \\
\hline RO11 & Nord-Vest & \\
\hline RO12 & Centru & \\
\hline RO2 & Macroregiunea doi & \\
\hline RO21 & Nord-Est & \\
\hline $\mathrm{RO} 22$ & Sud-Est & \\
\hline RO3 & Macroregiunea trei & \\
\hline RO31 & Sud - Muntenia & \\
\hline RO32 & Bucuresti - Ilfov & \\
\hline RO4 & Macroregiunea patru & \\
\hline RO41 & Sud-Vest Oltenia & \\
\hline RO42 & Vest & \\
\hline \multicolumn{3}{|c|}{ Sweden (SWE) } \\
\hline SE1 & Östra Sverige & \\
\hline SE11 & Stockholm & \\
\hline SE12 & Östra Mellansverige & \\
\hline SE2 & Södra Sverige & \\
\hline SE21 & Småland med öarna & \\
\hline SE22 & Sydsverige & \\
\hline SE23 & Väst sverige & \\
\hline SE3 & Norra Sverige & \\
\hline SE31 & Norra Mellansverige & \\
\hline SE32 & Mellersta Norrland & \\
\hline SE33 & Övre Norrland & \\
\hline \multicolumn{3}{|c|}{ Slovenia $(S V N)$} \\
\hline SI3 & Vzhodna Slovenija & \\
\hline SI4 & Zahodna Slovenija & \\
\hline \multicolumn{3}{|c|}{ Slovak Republic (SVK) } \\
\hline SK1 & Bratislavský kraj & \\
\hline SK2 & Západné Slovensko & \\
\hline SK3 & Stredné Slovensko & \\
\hline SK4 & Východné Slovensko & \\
\hline \multicolumn{3}{|c|}{ United Kingdom (GBR) } \\
\hline UKC & North East (UK) & \\
\hline UKC1 & Tees Valley and Durham & \\
\hline UKC2 & Northumberland and Tyne and Wear & \\
\hline UKD & North West (UK) & \\
\hline UKD1 & Cumbria & \\
\hline UKD3 & Greater Manchester & \\
\hline UKD4 & Lancashire & \\
\hline UKD6 & Cheshire & \\
\hline UKD7 & Merseyside & \\
\hline UKE & Yorkshire and The Humber & \\
\hline UKE1 & East Yorkshire and Northern Lincolnshire & \\
\hline UKE2 & North Yorkshire & \\
\hline UKE3 & South Yorkshire & \\
\hline
\end{tabular}

Code Name Level

UKE4 West Yorkshire

UKF East Midlands (UK)

UKF1 Derbyshire and Nottinghamshire

UKF2 Leicestershire, Rutland and Northamptonsh. 2

UKF3 Lincolnshire

UKG West Midlands (UK)

UKG1 Herefordshire, Worcestershire and Warwicksh 2

UKG2 Shropshire and Staffordshire 2

UKG3 West Midlands 2

UKH East of England 1

UKH1 East Anglia 2

UKH2 Bedfordshire and Hertfordshire 2

UKH3 Essex

UKI London

UKI3 Inner London - West

UKI4 Inner London - East

UKI6 Outer London - South

UKI7 Outer London - West and North West

UKJ South East (UK) 1

UKJ1 Berkshire, Buckinghamshire and Oxfordshire 2

UKJ2 Surrey, East and West Sussex 2

UKJ3 Hampshire and Isle of Wight 2

UKJ4 Kent

UKK South West (UK)

UKK1 Gloucestershire, Wiltshire and Bristol

UKK2 Dorset and Somerset

UKK3 Cornwall and Isles of Scilly 2

UKK4 Devon 2

UKL Wales

UKL1 West Wales and The Valleys 2

UKL2 East Wales

UKM Scotland

UKM2 Eastern Scotland

UKM3 South Western Scotland

UKM5 North Eastern Scotland

UKM6 Highlands and Islands

UKN Northern Ireland(UK) 